\title{
RUM(I)S AS THE REFERENCE TO THE TURKS AND PERCEPTIONS IN THE MALAY WORLD
}

\author{
Mehmet Özay *
}

\begin{abstract}
Rumis, who are identified as the seafarers and warriors in the Ottoman State, had an impact in the regions as a diasporic group exercising their professions from the West Asia through India and till Southeast Asia. It is comprehended that this concept, referring to both a geographical and cultural environment, was diffused among distinct state's formations throughout the centuries in the Asia Minor. Pertaining to Islamization of Turks and their gaining territorial sovereignty in that geography, a certain group of people classified under this title became subject of mobilization by some explicit reasons. In particular, the awareness of the relevant geographies, expansion of trade routes and the requirement of the skilled warriors by the principalities in North-Western Indian and Malay Archipelago are the reasons for the small or larger groups of Rumis to have travelled by their own capacities under certain conditions to some extent, beyond their function in the expansion process of the Ottoman State. This research is based on some primary sources including archival documents and secondary works from distinct geographies which are taken into consideration by comparative and interpretation approaches. The present writer briefly discusses the existence of Rumis, how this group represented themselves in the adjacent regions to the Indian Ocean and in which way the the concept of Rum/is was perceived, in particular, in the Malay genealogies and people in general in the course of time. It is expected that this study would provide additional narratives on the Rumi Turk in the Indian Ocean.
\end{abstract}

Keywords: Rumis, the Ottomans, Malay Sultanates, Indian Ocean, Southeast Asia

\section{Introduction}

As a preliminary study, I will, in particular, take considerations the issue of the connectivity of the larger Turkic nations, their activities in the broad region of the Indian Ocean and affiliation to the courts and global trade businesses in this large ocean and its expansion through the Malay World. Though Turks are known as the major actor in Central Asia and through the succession migrations on the course of centuries, say, from 5th century onwards, ${ }^{1}$ it is quite an interesting research area what their place was in the adjacent regions in the Indian Ocean. In this regard, it is also interesting to witness that Rumi epithet emerging in the various texts considering India and especially Malay World such as from Minangkabau, Aceh and the rest of Sumatra, till Bugis court in Sulawesi Island and partially in Java Island are concrete extension of Turkic elements who were recognized as nations in land-locked regions in farther geographies. ${ }^{2}$

In addition to their existence in some port cities and principalities of western India, Turks (Rumi) have gained popularity among the common folks throughout the history. In this respect, there is quite distinct works referring to Turks (Rumi) and relevant titles in different perspectives. The existence of Turkic elements in the region has attracted attention of some researchers such as Salih Özbaran (2007), İsmail Hakk1 Uzunçarşıl1 (1951), Vladimir Braginsky (2015), ${ }^{3}$ Affan Seljuk (1980), Barbara Watson Andaya

\footnotetext{
* Mehmet Özay (PhD), Assistant Professor, Department of Sociology, Ibn Haldun University, Başakşehir, İstanbul, 34494. Email: mehmet.ozay@ihu.edu.tr.

${ }^{1}$ Scott Levi (2007), "Turks and Tajiks in Central Asian History," in Jeff Sahadeo \& Russell Zanca (eds.), Everday Life in Central Asia Past and Present, Bloomington: Indiana University Press, p. 18.

${ }^{2}$ It is argued that there are 61 sub-Turkic groups on the basis of an authentic historical account titled Shajra-i Ansab (the book of genaologies) written by Muhammad bin Mansur bin Said or better known as Fakhr-i Mudabbir in India. See: Iqtidar Husain Siddiqi (1994), “The Turks and Their Migration To Central Asia and India," Proceedings International History Congress (IHC), 55th Session, p. 179.

${ }^{3}$ There are a significant number of references in various literary textes which were determined by the research of Vladimir Braginsky upon the usage of Rum and relevant titles. For instance, Malay Concondance, 2014, according to this project, in which 135 works in prose and verse represent traditional Malay literature, the key words of the Turkic-Turkish theme, 'Rum', Turk', 'Turkestan' and 'Istanbul'-occur about 1200 times in more than 40 texts. Even considering that the words 'Rum' and 'Turk' can repatedly appear as components of proper na mes and titles (Ghar Turki, Mughan Turk, Raja Rum and so on) which reduces the number of their relevant mentions by a third if not by half, they are still found in these 40 texts no fewer than 600 times, which is quite a lot." See: Vladimir Braginsky (2015), "Introduction," The Turkic-Turkish Theme in Traditional Malay Literature: Imagining the Other to Empower the Self, Ledien: Brill, p. 3.
} 
(1977), ${ }^{4}$ Cemal Kafadar (1996) and M. Longworth Dames (1921) among some others who contributed signifiantly to a further understanding of this subject by discussing the existence of Rum and relevance concepts to their recognition as Turk in coastal cities of Western India, Sumatra and Java Islands and Malay Peninsula

This prolonged observation supported personal witnesses and experiences. I came across some individuals and families in various regions in the province and heard the stories from these people that they are descendants of some Turkish or Turkic families. Though it is difficult to prove these claims at the very first hand, there might have been some facts among these accounts and claims. Among these people, did few families share some written documents some of which are reproductions from the original jawi texts.

What makes the issue attractive and a subject of inquiry is the primarily significant local sources. There are some authentic sources written in Jawi Malayu such as Bustan'us Selatin, Hikayat Atjeh, Sejarah Melayu which are considered as the general historical accounts with inevitable mythological perspectives, and Hikayat Meukata Alam Iskandar Muda, Hikayat Iskandar Zulkarneyn, Hikayat Marong Mahawangsa, Hikayat Hang Tuha, Hikayat Meukota Alam etc. which are about the individual rulers or heroes in various regions of the Archipelago.

The honorific titles affiliated to Turkic names and symbols though existed in historiographic textes such as hikayats, the sources and exact relations between Turks and the Malay world still need to be scrutinized. Further, the Indian geography should to be evaluated considerably owing to the Turkic elements would had been active and displayed strong mobility between commercial emperoums in Indian coastal areas and the larger Malay Archipelago. In regard to this, there are some relevant accounts aligned with the roles and activities of Turkic groups in the above-mentioned authentic works. For instance, there were commercial activities in which Turkish traders involved along with other nationalities in Aceh. ${ }^{5}$

It is important to scrutinize the accounts of the Malay courts which referred to Turks or some other names such as Rum as a part of their ancestral origins and recruited Turkic mercenaries into their armies frontier and appointed as advisors some of them to native rulers. ${ }^{6}$ This subject is the present writer's starting point to deal in this article. Pertaining to this study, I would like to highlight some questions about the existence and attributes of the Turkic elements who were considered in esteemed positions by the native courts in immediate geographies in the Indian Ocean. All relevant references which are quoted in lesser or larger extend discussed in this article are expected to prove that the Turkic elements, particularly by the epithet of Rum and Rumi in historical texts, but not only limited by these two words, represent transregional context.

Some problematic areas in this subject should be highlighted in the inception of the paper. In terms of this, I think the most crucial one is about the differences or similarities between the terms emerged in large amount of historical texts both in the writing of native historical writings and the ones penned down by individual travellers and officiers took part in various positions in western colonial powers. Though the mentioned questions are still exist as grey areas in the study of Turkic elements in the adjacent regions to the Indian Ocean, it is also true that the relevant terms referring to Turkic elements encountered in various native historical accounts, travellers' notes and western colonial writings can be categorised accordingly on the basis of classification as traders, mercenaries, rulers, advisory staff at court etc. ${ }^{7}$

\footnotetext{
${ }^{4}$ Andaya promotes the word 'Rum' in one of her papers titled "From Anatolia to Rum" and it is understood in her statements that the Ottoman rulers were perceived symbolically and legendarily as 'Raja Rum'. See: Barbara Watson Andaya (1977), "From Rum to Tokyo: The Search for Anticolonial Allies by the Rulers of Riau, 1899-1914,” Indonesia, Vol. 24, p. 129.

${ }^{5}$ Imran Teuku Abdullah (1991), Hikayat Meukuta Alam: suntingan teks dan terjemahan beserta teuaah strüktur dan resepsi, PhD Dissertation, Seri İldep, Jakarta: Intermasa, p. 117.

${ }^{6}$ Halil İnalc1k \& Donald Quataert (eds.) (2005), An Economic and Social History of The Ottoman Empire, Vol. I: 1300-1600, Fifth Printing, Cambridge: Cambridge University Press, p. 321. (Note: The accounts of Fernao Mendes Pinto about the 300 Turkish warriors accompanied to the expedition of Sultan Aceh (Alaaddin Riayat Syah al-Kahhar) against the Bataks in Northern Sumatra. See: Fernao Mendes Pinto (1897), The Voyages and Adventures of Ferdinand Mendez Pinto, Henry Cogan (trans.), London: T. Fisher Unwin, p. 29.

7 M. Longworth Dames (1921), "The Portuguese and Turks in the Indian Ocean in the Sixteenth Century," The Journal of the Royal Asiatic Society, pp. 3-4.
} 
Hence, it is obvious that the issue needs more consideration particularly, on the positions of the Turkic elements, geographical expansion, and the native rulers and folks perspective. In addition, other intriguing question such as how to justify whether the Turkic groups, say, Turkish nation in contemporary era have acknowledged their ancestors' involvement in distinct aspects of social life and being employed by various principalities.

Before going into details of the phenomenon of Rum in Malay texts it is better to have a brief account about its connotation in early centuries. This phenomenon is probably clarified and quite understandable, if the meaning of Rum is briefly described according to historical establishment. In a general understanding of linguistically, the term Rum is a derivative word produced from Romawi, related to Roman Empire. In regard to this, the territorials both lands and sea(s) under the sovereignty of Roman Empire might be called as Rum. For instance, Ibn Fadzlan describes the Black Sea as the sea of Rum, ${ }^{8}$ and the Mediterranean is also referred as Bahr-i Rum/Bahr al-Rum. ${ }^{9}$ Because of the greatness of the Romans, the states inherited the former's territory to some or larger extent, were also connotated as Rum which cannot be just a territorial issue, but more than this and taken as a civilizational aspect which might have been regarded accordingly by other nations for Saljuqs and Ottomans. In this aspect, it is talked about the Ottoman State at least nominatively, as a "neo-Roman Empire". ${ }^{10}$

And it seems that there is a common agreement that the term Rum is a concept mentioned and accredited primarily in Arabic sources for the land of Byzantium, which was considered as the traditional representative of Rome, ${ }^{11}$ and the people who lived in that particular geography. The term of 'Rum', in fact an Arabic translation of the word 'Roma' the capital city of the Roman Empire, was referred by the Arabs to a larger geographical entity including Asia Minor (Anatolia) and Thrace (Rumeli). ${ }^{12}$ Further I should quote from Goitein that the word Rum "which was the common denomination for Byzantine and Italian as well as other West European merchants" was also used by the Hebrew for 'Greek'. ${ }^{13}$ There is also another interesting attribute pertaining to the geographical description of Rum in Indian sources. For instance, in Pre-Islam period the territory where the Turks settled was described as to be between China and Rum (Byzantium). ${ }^{14}$

\section{Acquiring of the land and epithet of Rum by the Saljuqs and Ottomans}

The Anatolian land which had been known as 'the land of Rum' by Arabs and Persians in pre-Islamic period, was inherited not only as a material territory but also as its unique title by the Saljuqs and Ottomans. ${ }^{15}$

The word Rum is naturally affirmed as the ruler in Anatolia in lesser extent and in contemporary Middle East or central axis of Islamic world. Accordingly, the Ottomans were known and referred as Rum and their rulers as "the Sultan of Rum". ${ }^{16}$ The Turks increasingly became infamous in the Muslim worlds as Rum for two main reasons, that is the territorial expansions molded through Seljuqi Turks from Abbasid dynasty to the western Arabia, followed with Ottoman inheritor of Byzantium. ${ }^{17}$

\footnotetext{
8 İbn Fazlan (1975), İbn Fazlan Seyahatnamesi: Onuncu Asırda Türkistan'da bir İslam Seyyahı, Ramazan Şeșen (trans.), İstanbul: Bedir Yayınevi, p. 104. (Note: Ibn Fadlan a 10th century Arab-Muslim traveller.) (Note: There is also reference to name Marmor Sea as the Sea of Rum in some authentic text. See: Ekrem Kamil (n.d.), Gazzi-Mekki Seyahatnamesi, (Hicri Onuncu-Miladi on altıncı asırda yurdumuzu dolaşan Arab Seyahlardan), Tarih Semineri Dergisi 1-2, İstanbul Üniversitesi Edebiyat Fakültesi Yayınları, III, İstanbul: Milli Mecmua Basımevi, p. 46.

9 İsmail Hakkı Uzunçarşılı (1951), Osmanlı Tarihi, III. Cilt, I. Kısım, Türk Tarih Kurumu Yayınlarından XIII. Seri, No. 16, Ankara: Türk Tarih Kurumu Basimevi, p. 10.

${ }^{10}$ Karen C. Pinto (2016), Medieval Islamic Maps: An Exploration, Chicago: The University of Chicago Press, pp. 168 \& 275.

${ }^{11}$ Halil İnalc1k (1964), "The Place of the Ottoman-Turkish Empire in History," Cultura Turcica, Institute for the Study of Turkish Culture, Volumen I, Numerus I, Ankara, p. 57.

${ }^{12}$ Dejanirah Couto (ed.) (2010), “Giris," Harp ve Sulh: Avrupa ve Osmanllar, Dejanirah Couto, Sirin Tekeli (trans.), İstanbul: Kitap Yayınevi, p. 17; Cornell H. Fleischer (1986), Bureaucrat and Intellectual in the Ottoman Empire, Princeton: Princeton University Press, p. 277.

${ }^{13}$ S. D. Goitein (2014), "Mediterranean Trade in the Eleventhy Century: Some Facts and Problems," in Studies in the Economic History of the Middle East: From the rise of Islam to the present day, London: Routledge, pp. 53-55.

${ }^{14}$ Iqtidar Husain Siddiqi (1994), "The Turks and Their Migration To Central Asia and India," Proceedings International History Congress (IHC), 55th Session, p. 177.

${ }^{15}$ Kütahyalı Firaki Abdurrahman Çelebi (2013), Se'adetname-Yavuz sultan Selim Han ve Kanuni Sultan Süleyman Han'ın Gazalarl (Haz.: Şaban Er), İstanbul: Kutupyıldızı Yayınları, pp. 209 \& 309; Howard Crane (1994), "Anatolian Saljuq Architecture and Its Links to Saljuq Iran," in Robert Hillenbrand (ed.), The Art of the Saljuqs in Iran and Anatolia: Proceedings of a Smyposium held in Edinburgh in 1982, California: Mazda Publishers, p. 264; Halil İnalcık (1948), "Osmanlı-Rus Rekabetinin Menşei ve Don-Volga Kanalı Teşebbüsü (1569)," Belleten, Türk Tarih Kurumu Cilt XII, Sayı 46, (Nisan), p. 350; Cemal Kafadar (2007), “A Rome of One's Own: Reflections on Cultural Geography and Identity in the Lands of Rum," Muqarnas, Vol. 24, p. 9.

16 Vladimir Braginsky (2015), "Introduction," p. 3.

17 Vladimir Braginsky (2015), "Introduction," p. 7.
} 
Once the Turks gained the political power and acquired a large territory first in Persian and partially north-western India during the time of the Great Saljuqi State in 11-13th centuries, and later periods the Ottomans from 14th century onwards, the same onthological and political reference continued to exist throughout the centuries. ${ }^{18}$ And as will be seen in the coming pages, the word Rum is also referred both by the Saljuqi and Ottoman military and civil bureaucracy. Once latter powers acquired the political sovereignty in almost the same territories of the Byzantium one after another, the other nations commenced to refer, using the same term Rum, to Turks. ${ }^{19}$

And it is also true that this word was neutrally inherited and voluntarily used by the Saljuqi Turks and later on by the Ottomans in the same context, say, for the referring to the geography and the people lived or came from a particular geography, e.g. provinces in Asia Minor. ${ }^{20}$ This is because of conquering a large part of Asia Minor gained initialy by the efforts of Alp Arslan and later on completed by Melik Shah. ${ }^{21}$ But as observed in some papers considering an authentic Malay text it is asserted that the word Rum is referred to both Anatolian Turk and the ones in Central Asia. ${ }^{22}$

In addition, the identity of these group of people who can be classified under the word Rum citing from an article of Cemal Kafadar who defines Turk and Rumi Turks discusses about merchants of Turkish origins in pre-modern Ottoman era. Kafadar says in relation to Turkish merchants connected to Byzantium just before the conquest event by Mehmed II, "Turk is used here in reference to Turkishspeaking Ottoman Muslims who whether converts of various autochthonous people or descendants of Central Asians who moved into Anatolia and the Balkans, came to mold -by fate or design- the Rumi Turkish cultural tradition". ${ }^{23}$ In regard to this, there is a connotation which is also salient understanding of this word's development in historical process. As asserted by Orhan Türkdoğan, Rumi is given as title to Christian individuals who were picked up and grown up by Turkish families on the basis of devshirmeh system. ${ }^{24}$

\section{The Geographical Reference of the Usage of Rum}

The words Rum and Rumi are understood from the geographical reference starting from the eastern part of Asia Minor, such as Malatya, where the Saljuqi initially gained access through conquering in the second part of the 11th century. Further, the provinces acquired one by one by the Saljuqi rule in Anatolia are considered as Rum places such as Arz-ar-Rum (Erzerum), Arzinçan, Diwrigi, Amasya, Nigdê, Niqsâr, Qaisaria, Irâqlia. As the continuity that the naming of these provinces seem to have been structured through administrative establishment during the time of Ottoman rule. For instance, the Ottomans gained the political and territorial sovereignity in the provinces of Ankûrya (Ahiler, Angora,

\footnotetext{
${ }^{18}$ M. Fuad Köprülü (1984), İslam Medeniyeti Tarihi, Altıncı Basım, Diyanet İșleri Başkanlığı Yayınları, No. 86, Ankara: Arısan Matbaacılık, p. 55; Halil İnalcık (1948), “Osmanl1-Rus Rekabetinin Menşei ve Don-Volga Kanalı Teşebbüsü (1569),” p. 350.

${ }^{19}$ Guy Le Strange (2015), Doğu Hilafetinin Memleketleri (Mezopotamya, Iran ve Orta Asya) İslam Fetihlerinden Timur Zamanına Kadar, (Haz.: Adnan Eskikurt; Cengiz Tomar), İstanbul: Yeditepe Yayınları, p. 173; Hagen Gottfried (2015), Bir Osmanlı Coğrafyacısı İşasında: Katip Çelebi’nin Cihannüma'sı ve Düşünce Dünyası, (Çev.: Hilal Görgün), İstanbul: Küre Yayınları, p. 336.

${ }^{20}$ Lawrence I. Conrad (2004), "Theophanes and the Arabic Historical Tradition: Some Indicationas of Intercultural Transmission," in Michael Bonner (ed.), Arab-Bytantine Relations in Early Islamic Times, Vol. 8, Surrey: Ashgate-Variorum, p. 237. (Note: In pertaining to this issue, once the Saljuqi rulers such as Izzeddin Keykavus (1211-120) had hegemony in the coastal area of the Black Sea, such as Sinop and around, they acquired some titles including 'The Rulers of Rum, Damascus and Armenia' ('Sultanü Biladi'r-Rum ve'ş-Şam ve'l-Ermen). In addition, then the khalifah en-Nasır Lidinillah (1180-1225) mentioned Izzeddin Keykavus as 'the ruler of Rum' (Melikü Biladi'r-Rum). See: Salim Koca (1995), “Türkiye Selçuklu Sultanı I. İzzeddin Keykavus’un Aldığı ve Kullandığı Hakimiyet Sembolleri,” Belleten, Atatürk Kültür Dil ve Tarih Yüksek Kurumu, Türk Tarih Kurumu, Cilt LIX, S. 224, (Nisan), Ankara: Türk Tarih Kurumu Basımevi, p. 57; Oruç Bey Tarihi, (Haz.: Necdet Öztürk), İstanbul: Çamlıca Basım Yayın, p. 4; Walther Hinz (1992), Uzun Hasan ve Șeyh Cüneyd: XV. Yüzyılda İran'ın Milli Bir Devlet Haline Yükselişi, (Çev.: Tevfik Bıyıklığlu', Atatürk Kültür Dil ve Tarih Yüksek Kurumu, Türk Tarih Kurumu Yayınları, IV. Dizi, Sa. 5, Ankara: Türk Tahik Kurumu Basımevi, p. 63; Seydi Ali Reis (n.d), Mir'at-ül Memalik: Ülkelerin Aynası, Baskıya Hazırlayan: Necdet Akyıldız, Tercüman 1001 Temel Eser, İstanbul, p. 75. (Note: Some provinces which are referred as 'Rum' are encountered in special documentations such as accounting reports prepared on yearly based in the Ottoman State. (See: Ahmet vd. Özkılınç (1996), (Haz.). Muhasebei Vilayet-i Karaman ve Rum Defteri. (937/1530), I, Konya, Bey-şehri, Ak-şehir, Larende, Aksaray, Niğde, Kaseriyye ve İç-il Livaları, Ankara: T.C. Başbakanlık Devlet Arşivleri Genel Müdürlüğü Osmanlı Arşivi Daire Başkanlığı Yayın Nu. 32, Defter-i Hakani Dizisi: III, 387 Numaralı; BOA, TT.D.287 / 961.Z.29 (25 November 1554).

${ }^{21}$ Lawrence D. Higgins (1994a), “Turkic Empire,” in Franklin D. Margiotta (ed.), Brassey's Encyclopedia of Military History and Biography, Washington: Brassey's, p. 1008; Lawrence I. Conrad (2004), “Theophanes and the Arabic Historical Tradition,” p. 237.

22 Affan Seljuq (1980), "Relations Between The Ottoman Empire and the Muslim Kingdoms in the Malay-Indonesian Archiapeloge," Der Islam, Vol. 57, p. 302.

${ }^{23}$ Cemal Kafadar (1996), “A Death in Venice (1575): Anatolian Muslim Merchants Trading in the Serenissima,” in Sanjay Subrahmanyam ed.), Merchant Networks in the Early Modern World, Aldershot: Varioum, p. 99.

${ }^{24}$ Orhan Türkdoğan (2002), Osmanlıdan Günümüze Türk Toplum Yapısı, İstanbul: Çamlıca Yayınları, p. 150; Halil İnalcık (2017), Osmanlı Tarihinde İslamiyet ve Devlet, İstanbul: Türkiye İş Bankası Kültür Yayınları, p. 179; M. Longworth Dames (1921), "The Portuguese and Turks in the Indian Ocean in the Sixteenth Century," The Journal of the Royal Asiatic Society, p. 11.
} 
Ankara) in $1354 .{ }^{25}$ In addition to this classification of the provinces in Asia Minor, Halil İnalcık also refers to few provinces such as Amasya and Sivas as Rumi cities and establishments. ${ }^{26}$

The process emerged while the Ottomans, then a smaller principality in western Anatolia, attempted first to expand in eastern Balkania in the end of the 15th century, and later on targetted principally Constantinople, the center of Eastern Rome empire, and once the center of emporium with the trade conducted with the Eastern geographies. And the goods from both overland through India, Iran and Asia Minor and the across the Mediterranean Sea via the Red Sea. ${ }^{27}$ The conquest over Constantinople, the head of Byzantium regarded as the "traditional representative of Rome", by the Ottomans caused the recognition of the Conquerer as 'Sultan of Rum', say, the ruler of Roman land, ${ }^{28}$ or as the emperor of Rome (Kayser-i Rum) as inheritor of the Eastern Rome empire. ${ }^{29}$

Some sources mention Rum, Rumi and similar other expressions as the rulers with some identifying titles such as "Ghar Turki, Mughan Turk, Raja Rum" in particular polities in the adjacent regions in the Indian Ocean. As mentioned in the initial pages of this article, there were a number of sub-Turkic groups, some of whom gained a distinguished place in the history of the region on the basis of their successful establishment of statecraft. ${ }^{30}$

The Ottoman utilized word Rum in the geographical context, approximately equals to the provincial preference. In regard to this, the Ottoman administration, divided as provinces, talks about "Rum diyarl" on the basis of some certain regions in the larger territories of the state bureucracy. And this usage is commonly met in written sources both early centuries and particularly after the gaining the political sovereignty and protection of the Holy Land after 1517. Interestingly these territories including some areas such as Syria, Egypt, Iraq and coastal areas of Northern Africa. ${ }^{31}$

Both Ottoman sources and some foreign references to Rum should be taken into consideration with a specific geographic area in Anatolia or Asia Minor, such as Karaman, Teke and Hamideli in southern part of the region. In this light, it is seen that the reference to Anatolia as the land of Rum is also encountered in the text about the development of Safavid State in 15th century. It is understood that some Turcoman groups from the southern part of Turkey, say, settled in Karaman, Teke, Hamideli, around Taurus Mountains, mobilized at least for a short period of time to northern Iraq (Erdebil). And these groups were referred as the ones coming from the land of Rum. ${ }^{32}$

In this regard, the usages of Bilad al-Rum, al-Ard al-Kabira min al-Rum, Bahr al-Rum to refer to the geography of the Roman Empire by other adjunct nations and kingdoms. ${ }^{33}$ The similar expressions might be found in some other provinces, such as in central Anatolia which are accounted as diyar-l Rum (Rum lands).$^{34}$ It is believed that there is an implicit relationship between these sorts of references and a historical fact which is relevantly related to the conquest under Ala Al-Din Qayqubad of Saljuq the regions including Konya, Kayseri, Sivas from the Greek. ${ }^{35}$

\footnotetext{
${ }^{25}$ Peter Truhart (1996), Historical Dictionary of States: States and State-like Communities from Their Origins to the Present, München: K. G. Saur, p. 331; Ülkü Ü. Bates (1994), “Evliya Çelebi's Comments on the Saljuqs of Rum,” in Robert Hillenbrand (ed.), The Art of the Saljuqs in Iran and Anatolia: Proceedings of a Smyposium held in Edinburgh in 1982, California: Mazda Publishers, p. 259. (Note: Erzurum is also referred as "Erzan al-Rum" in the following source. See: Thomas D. Goodrich (1990), The Ottoman Turks and the New World: A Study of Tarih-i Hind-i Garbi and Sixteenth Century Ottoman Americana, Wiesbaden: Otto Harrassowitz, p. 415.

${ }^{26}$ Halil İnalc1k (1973), The Ottoman Empire: The Classical Age 1300-1600, Norman Itzkowitz \& Colin Imber (trans.), London: Weidenfeld and Nicolson, p. 73; Ülkü Ü. Bates (1994), "Evliya Çelebi's Comments on the Saljuqs of Rum,” p. 259. (Note: The Ottoman archival documents refer also some provinces such as Tokad and Sivas in the territory of vilayet-i Rum. See: BOA, TT.D.287/961.Z.29 (22 November 1554).

${ }^{27}$ Charles Mac Farlane (1854), History of British India, London: Routledge, p. 4.

${ }^{28}$ Metin Kunt (1984), "The Later Muslim Empires: Ottomans, Safavids, Mughals," in Marjorie Kelly (ed.), Islam: The Religious and Political Life of a World Community, New York: Praeger, p. 119; Halil İnalcık (1964), "The Place of the Ottoman-Turkish Empire in History," Cultura Turcica, Institute for the Study of Turkish Culture, Volumen I, Numerus I, Ankara, p. 57.

${ }^{29}$ Halil İnalcık (2017). Devlet-i 'Aliyye: Osmanlı Imparatorluğu Üzerine Araştırmalar-II, 5. Baskı, İstanbul: Türkiye İş Bankası Kültür Yayınları, p. 65.

${ }^{30}$ Vladimir Braginsky (2015). "Introduction,” p. 3; Iqtidar Husain Siddiqi (1994). "The Turks and Their Migration To Central Asia and India," p. 179.

${ }^{31}$ Metin Kunt, Hüseyin G. Yurdaydın \& Ayla Ödekan (1988), Türkiye Tarihi (2), Osmanlı Devleti: 1300-1600, İstanbul: Cem Yayınevi, p. 103 .

32 Walther Hinz (1992). Uzun Hasan ve Şeyh Cüneyd: XV. Yüzyılda Iran ’ın Milli Bir Devlet Haline Yükselişi, p. 63.

${ }^{33}$ Karen C. Pinto (2016). Medieval Islamic Maps: An Exploration, pp. 168 \& 274; Guy Le Strange (2015), Doğu Hilafetinin Memleketleri, p. 173.

${ }^{34}$ BOA, Y.EE.37.104/1327.R.06.(1) (27 April 1909).

35 Ülkü Ü. Bates (1994), “Evliya Çelebi’s Comments on the Saljuqs of Rum,” p. 259.
} 
Pertaining to this geographical reference can be also found Evliya Çelebi's account, a famous traveller, during the 17th century. He names the Saljuqs with the rerefence to their being the rulers in Asia Minor by arguing Saljuqs of Rum originally came from the Mahar, Transoxiana with some other Turkic groups and through some province such as Niksar, Amasya, Kayseri, Sivas and they reached Konya and determined this city as the capital city of the state. On the course of short period, the Saljuqi conquered some provinces known as Rum such as Kayseri, Sivas and he states that Osman Ghazi, the founding father of the Ottoman State, inherited the political sovereignty of the Saljuqi. ${ }^{36}$

Related to the usage of the term Rumi, there is another form encountered as Rumiyan, for instance during the reign of Sultad Bayezıd I, in particular, which means Muslim soldiers originally Turk. In regard to this, there is obviously a continuity of the term Rum to refer to Asia Minor as observed during the reign of Sultan Bayezıd I and later periods. ${ }^{37}$ For instance, the expression of 'Land of Rum' is also mentioned by Piri Reis, Diyar-l Rum, in the form of Ottoman language, as an indication of Anatolia belonging to Sulaiman II, then Ottoman Sultan, when he presented his famous work 'Kitab-l Bahriye' to him $1526 .^{38}$ And it is common to encounter the expression of Rum in Ottoman archival documents which talk about various issues and topics, including in the matters of concubine or cariyya. ${ }^{39}$

One can assert that this continuity of naming the relevant provinces during the realm of the Saljuqi Turks to Ottoman Turks in Anatolia was a smooth and natural one. Since the Ottoman was a vassal emirate of the Seljuq Sultanate of Rum. ${ }^{40}$ Against the idea of some researchers about the usage of the term Rum for a certain individuals such as Selman Reis, Murat Reis, Piri Reis and Seydi Ali Reis in the Ottoman State, one asserts that this title was maximally functionalized by either Ottoman citizens themselves in various geographies in India and the Archipelago or the people in those geographies called these outsiders from the Asia Minor as Rum/Rumi. ${ }^{41}$ This latter aspect is encountered in the Portuguese accounts pertaining to their observations and experiences in the Western Indian shores, including Basra Bay, describing a group of Muslim people as Rumes who were referred the ones living originally in the land under the control of Ottomans sultans. ${ }^{42}$

The references to the identity of Turks in the East, say, India and the Malay world, are attributed to the words of Rum, Rumi, Turcoman or time to time Turk itself. ${ }^{43}$ In addition, these references could be analysed on the basis of various contexts such as geography, trade, history and art, titles for individuals playing a crucial function in society, being religious scholars, traders and mercenaries. ${ }^{44}$

Further these foreign groups also contributed to the internationalization of the local courts sharing their expertise, creating a legitimacy of the native court circles and against this they were given some certain status in the courts and protected by the rulers as well. As it is mentioned in some literature for instance, in the context of the inner seas such as, Aegeian and Mediterranean seas the seafarers who were named as Rumi involved in maritime trade, too, beyond having warrior carreer in the region. ${ }^{45}$

\section{Reflections of Rum and Structuring Malay Worldview in Hikayats}

It is crucial to decide what designate of the usage of the word Rum in various texts which the present writer will find to touch briefly in this article. Rum, as attributed to the Turk, for instance, in Malay courts reflects a civilizational contact between expanding and shifting relevant geographical sovereignities such as Malay and Turkic ones. Authentic sources from Malay court in Minangkabau, ${ }^{46}$

\footnotetext{
36 Ülkü Ü. Bates (1994), “Evliya Çelebi’s Comments on the Saljuqs of Rum,” p. 259.

${ }^{37}$ Cemal Kafadar (2007), “A Rome of One's Own,” p. 7.

${ }^{38}$ Christine Isom-Verhaaren (2014), "Was there Room in Rum for Corsairs?: Who Was an Ottoman in the naval Forces of the Ottoman Empire in the 15th and 16th Centuries?," The Journal of Ottoman Studies, Vol. 44, p. 236.

${ }^{39}$ BOA, TS.MAe.1304.67.(1248.Z.1 / 21 April 1833). (Note: It is about the setting free of Greek born Gulferah and Circassian Gulfidani binti Abdullah by al-Hajj Mehmed Emin Efendi, the former clerical of Sultan Selim III).

${ }^{40}$ Lawrence D. Higgins (1994b), “Ottoman Empire," in Franklin D. Margiotta (ed.), Brassey's Encyclopedia of Military History and Biography, Washington: Brassey’s, p. 746.

${ }^{41}$ Christine Isom-Verhaaren (2014), "Was there Room in Rum for Corsairs?,” pp. 236-237; Şehabeddin Tekindağ (1968), “Süveyş’de Türkler ve Selman Reis'in Arızası,” Belgelerle Türk Tarihi Dergisi, Cilt 2, Sayı 9, Haziran, p. 77.

42 Salih Özbaran (1972), "The Ottoman Turks and The Portuguese in the Persian Gulf, 1534-1581,” Journal of Asian History, Vol. 6, p. 47.

${ }^{43}$ Cemal Kafadar (1996), “A Death in Venice (1575),” p. 97.

${ }^{44}$ For instance, the early centuries there were two sorts of classification of ornamentation. One of these is Rumi whose figures are attributed to plants such as dal-kırma (broken or undulating branches), zülf-i nigar (side lock of a beauty, a species of flower as well), nilüfer-i cin (peony). See: Ülkü Ü. Bates (1994), "Evliya Çelebi’s Comments on the Saljuqs of Rum,” p. 259.

${ }^{45}$ Christine Isom-Verhaaren (2014), "Was there Room in Rum for Corsairs?,” p. 241.

${ }^{46}$ The bound of Minangkabau to the concept of Rum can be traced in some Dutch colonial writings about West Sumatra as follow: “... kepada bumi jang sutji antara Maşrik dan Mağrib antara timur dan selatan antara bukit Siguntang Pendjaringan itulah namanja tanuh Rum ...” See:
} 
$\mathrm{Jambi}^{47}$ in Sumatra and Johor ${ }^{48}$ Malaya revealed this reference from 14th to 19th century supports the argumentation that there was, on one hand, a civilizational and courteous connection between the Malay world and the Turkish ones. The term 'Rumi' with 'Turki' at the same time, in a manner of exception, is used to refer to a type of horse which seems to have been in Aceh during Iskandar Muda. ${ }^{49}$

Here a question can be brought front whether there were any impacts and influences of the existence of Turkic elements, either directly or indirectly, in the Asian and Southeast Asian geographies, more essentially, in the 16th century which witnessed the expansive and successful states such as Isfahan, Agra and Acheh -with two others including Istanbul and Morocco- asserted by Wilfred Canthell Smith. Since these states emerged as the powerful and wealthy political sovereignty in the same epoch in which the Turks under distinct names and dynasties or Rumi groups left their signs. ${ }^{50}$

I would like to touch briefly the usage of Rum in some authentic texts from Malay world. Rum is mentioned as a place, say, Asia Minor, in Hikayat Iskandar Zulkarnain, a text produced in Aceh, in relation with the Qur'anic verse talking about a magnificent figüre called Zulkarnain. ${ }^{51}$ For instance, the reference through Rum in Hikayat Hang Tuah, the name of the actor in the story who is believed to have lived during the reign of Malacca Sultanate, is directly equated with Istanbul. ${ }^{52}$ Tough this assummed relation whose authenticity is yet to be discovered on the basis of factual data, some of the Malays in Malay Peninsula pay more attention on this matter.

In addition, another infamous account called as the Kedah Annals, getting its name from the northern province of Malaya, Kedah, narrates the relation between the ruler of Rum, and Marong Mahawangsa, an ambassador on behalf of the ruler of Rum, understood a native in Kedah, to join the envoy despatched to reach China for the rulers son and daughter's marriage. ${ }^{53}$

This is quite interesting account which put Kedah Malay history a sort of merging between eastern and western empires in the form of this marriage case. While considering some similarities even the expressions in these mentioned reference books penned down in distinct geographies and sultanates in the region, it is highly possible that the relevant policies resulted in connections to lesser or larger extent or these works were distinguishedly subject to mobilization throughout the scholars and their students.

There is a context in which the word Rum refers to either Alexander the Great and implicitly Greek civilization or Zulkarnein as linked to the narratives of the Holy Qur' an continously debatable. In regard to this, there is an interesting witness/view that the concept of Rum is referred to Alexander the Great in some papers about the genealogy of Minangkabau people. ${ }^{54}$ In this regard, one of the sources asserts

Oendang Oendang van Sumatra's Westkust, Ms. Orient Oct. 1111 (Malaiisch) Akzessionnummer: 1906.284. Or 637 (146) Malay manuscript/Laufende Nr. 2, p. 2 (1-9).

${ }^{47}$ For the reference of a Turkish proselytizer pertaining to the Islamization of Jambi people. See: Rachman Lukman (1983), Sejarah Perlawanan Terhadap Kolonialisme dan Imperialisme di Jambi, Proyek Inventarisasi dan Dokumentasi Sejarah Nasional, Jakarta: Departemen Pendidikan dan Kebudayaan, p. 7.

${ }^{48}$ The marriage of Sultan Abu Bakar with Hatice Hanım (Che Khatijah Hanum) who is assumed to be descendant of Turk. See: Na Tian Piet (1896), Shaer Almarhoem Beginda Sultan Abubakar Di Negeri Johor, Bagian Yang Pertama. See for details: Mehmet Özay \& Ekrem Saltık (2015), "The Myth and Reality of Rukiye Hanım in the Context of Turkish Malay Relations (1864-1904)," The Journal of Human\&Society, Vol. 4, no. 9, 55-74.

${ }^{49}$ T. Iskandar (1966), Bustanu's-Salatin, (Nuru'd-din ar-Raniri), Bab II, Fasal 13, Kuala Lumpur: Dewan Bahasa dan Pustaka, p. 40. (Note: Hikayat Aceh gives information about two Çelebis, Ahmed and Ridvan, looking for drug for the uncured illness of the Ottoman Sultan, who seems to be Mustafa I, at initial decades of the 17th century, during the era of Iskandar Muda. See: T. Iskandar (1958), De Hikajat Atjeh, S. Gravenhage-Martinus Nijhoff, p. 161; T. Iskandar (1978), Hikayat Aceh: Kisah Kepahlawanan Sultan Iskandar Muda, (Çev.: Aboe Bakar), Proyek Rehabilitasi Dan Perluasan Mesuem Daerah Istimewa Aceh, Seri Publikasi Nomor 1, pp. 176-177. (Note: In addition to these Hikayat and the native accounts, a similar reference of Negeri Rum occurs in a letter sent by Sultan Mansur Syah of Aceh to the Ottoman court in the middle of the 19th century. See: BOA, İ.HR.66.3208.6.1. (29.B.1266/10 Haziran 1850). (Note: Saffet Bey affirms the reference to the concept of Raja Rum in Acehnese letter sent in the second part of the 16th century in his famous text. And he recontextualizes this concept converting it to 'Sultan of Turkey'. See: Saffet Bey (1329/1909), "Bir Osmanl Filosunun Sumatra Seferi," Tarih-i Osmani Encümeni Mecmuas1, 1, p. 604. (Note: It is understood that Thomas Stamford Raffles had a similar observation during his being in Aceh in the beginning of the 19th century. He argues that he encountered some documents informing about the past relations of the Sultanate of Aceh including Aceh's tributary state to Rum (Ottoman State). See: Sophia Raffles (1830), Memoir of the Life and Public Services of Sir Thomas Stamford Raffles, London: John Murray, p. 384.

${ }^{50}$ Wilfred Canthell Smith (1957), Islam in Modern History, Princeton: Princeton University Press, pp. 35 \& 38.

${ }^{51}$ Nindya Nugraha (2002), Hikayat Iskandar Zulkarnain \& Syair Raja Siak, Dari Naskah W113\&W273, Jakarta: Perpustakaan Nasional RI, p. 1.

52 Vladimir Braginsky (2015), “Introduction," p. 3.

${ }^{53}$ Marong Mahawangsa: The Keddah Annals, (2012). Kuala Lumpur: Silverfish Books, pp. 11 \& 13.

${ }^{54} \mathrm{Su}$ Fang Ng (2006), "Global Renaissance: Alexander the Great and Early Modern Classicism from the British Isles to the Malay Archipelago," Comparative Literature, Vol. 58, no.4, p. 293. According to the story, three brothers left India for reaching three distinct geographies. And one of them, named as Sri Maharaja Diraja or Sri Mahara settled in Mount Merapi, Minangkabau. The other two set off to 
that the first king of Minangkabau in Sumatra Island was the son of a Prince of India and of race of Raja Sekandar Zulkarneini, or Alexander the Great. ${ }^{55}$ The same relevancy of genealogy of the Sultanate of Malacca to acquire political legitimacy emerged in the attribution of the state to Alexander the Great. ${ }^{56}$

But, there is also an interesting discussion among the local scholars as perceived from the written texts that Zulkarneyn which is the name used for Alexander the Great, might be referring to the story of Zulkarneyn in the Holy Qur'an. And no doubt that the Hikayat Iskandar Zulkarnain is an important text for understanding of the scope of the Malay weltanschaaung. ${ }^{57}$ This is a point worth further studies in the context of constructing narratives of the Malay folks in early centuries. Argumentation of its reference to Turkic context in major texts is variously and dynamically founded by the court historians and foreign writers such as travellers, scholarly colonial staff etc. Such contextual interpretation reflects the realities of the Malay world to be connected and considered within a larger civilizational framework.

Beyond this fundamental discussion, it should be said that the former referrence is quite significant and determinative. Because Minangkabauan people are considered as the original Malay folk whose migration from the Western Sumatra both to the Eastern Sumatra and also to Malaya by crossing the Malacca Strait in later centuries. I should remind here that though this connection is mostly seen in Sumatra and Malaya, I am not going to argue that the ancestral accounts of the other parts of the Malay Archipelago either support or disregard this phenomenon. But at least, I have not encountered any similar accounts directly or indirectly in any authentic local texts, let's say, in Java community, or Sulawesi.

I think that the concept and perception of the word Rum was well established since it was seen as the ancestral root of the Malay folk. And it can be traced in the authentic local writings and the adjacent regions to the Indian Ocean and the Archipelago historically. Such that, it is observed that the settlement of the Turkic groups appeared in early centuries while the latter from Turkistan were acquired as slaves to be soldiers during Delhi Sultanate in 13th century. And after that, the mobilization of the Turkic segments continued either by their own efforts or by the external factors. ${ }^{58}$

Here one should remember that the Turkic segments in Indian port cities might have followed the same route followed by the Muslim Arabian and Persian prosetilysers and of course traders reached in the Archipelago from the northern tip of Sumatra Island. And a concrete fact appeared in the first hand information of Ibn Battuta who observed some similarities between Pasai and Delhi courts in the middle of the 14th century. ${ }^{59}$ It is also observed a similar link between Aceh and Delhi sultanate, if we consider accordingly that Ali Mughayat Syah al-Kahhar, third sultan of the Sultanate of Aceh Darussalam, gave his third son Mughal as his name. ${ }^{60}$

I should emphasize here the religious dimension of this reference. Such that the phenomenon of conquering Constantinople in the middle of the 15th century gained a dominant importance in the perception of the Rum concept among the Malay folks relevant with the Islamization of the latter throughout the history. Ottoman Turks' accomplishment of gaining the sovereignty of Constantinople, which event was linked to a hadith of Prophet Muhammad ( $p b u h)$, creates significant effect on Acehnese Muslims, like many other Muslims in the region. This religious link is prominently observed in the writings of Nuru'din ar-Raniri, infamous influential scholar invited to the Acehnese court in the early decades of the 17 th century. ${ }^{61}$

go China and Rum. As a proof of this accounts, some characteristics of Indian culture such as language aspect, the Hindu sites and residue are referred. See: "Moelanja Igama Islam diketahoei di Minangkabau," Fadjar Islam, No. 15, Djoem'at 31 Januari 1930 / 1 Ramadhan 1348, Tahoen II, p. 333.

${ }^{55}$ Marong Mahawangsa: The Keddah Annals (2012), Kuala Lumpur: Silverfish Books, p. 23.

${ }^{56}$ Paul Coatalen (1981), "The Coming of Islam to Southeast Asia: A Critical Review of Some Extant Theories," The Islamic Quarterly, Vol. XXV, no. $3 \& 4$, p. 106 .

${ }^{57}$ Majid Daneshgar (2016), "Dhu 1-Qarnayn in modern Malay commentaries and other literature on Qur'anic themes," in Majid Daneshgar, Peter G. Riddell \& Andrew Rippin (eds.), The Qur'an in the Malay-Indonesian World: Context and Interpretation, London: Roudledge, pp. 212-213.

${ }^{58}$ Iqtidar Husain Siddiqi (1994), “The Turks and Their Migration To Central Asia and India,” pp. 176-177; E. Denison Ross (1929), "Nomadic Movements in Asia," Journal of the Royal Society of Arts, Vol. 77, no. 4010, p. 1086.

59 T. W. Arnold (1968), The Preaching of Islam: A History of the Propagation of the Muslim Faith, Third Reprint, SH. Muhammad Ashraf, p. 368 .

60 T. Iskandar (1966), Bustanu's-Salatin, p. 32.

61 T. Iskandar (1966), Bustanu's-Salatin, p. 31. 
A similar vein is observed to have emerged in the classical writings of Hikayats. In this light, Vladimir Braginsky points this issue in his recent publication and asserts that there are 135 classical Malay works mentioning Rum, Turk and relevant terminology. ${ }^{62}$ In another aspects, as encountered in even few texts the words Turk and Muslim can be used in place of each other. For instance, Bulli Shah, a sufi poem of India in 18th century, uses Turk but in the intention of referring as Muslim in one of his poems. ${ }^{63}$

The word Rumi could be found consistently in Malay texts, which will be further elaborated below. But this reference is hardly possible to encounter in written documents in late centuries, say, the 19th century and oral accounts, in the 20th century. In particular, it is closely observed that its absence is traced in Acehnese written works or oral history, for instance, the authentic sources such as Hikayat Aceh, Bustan'us Salatin mentioning the term of Rumi or relevant concepts which are considered as proofs for the connection between the Ottomans and the Aceh Darussalam Sultanate. At least, I can assert that the connectivity of the Acehnese with the Turkic elements were exist as understood from the reference to the types of horses rode by Turks and Rumi in Bustan 'us Salatin. ${ }^{64}$ In addition, it is observed that the usage of this word in the story referring to a ruler in Ottoman State and the envoys sent by the mentioned ruler to Aceh to find the relevant plants which were believed to be ingredients to cure in the early decades of the 17 th century ${ }^{65}$ Hence, the Acehnese folk including rural communities significantly recognize the concept of Turk where military power and accomplishments of the Ottoman State were mainly referred.

\section{Legitimay of the Dynasties (Gayo-Minangkabau)}

To be able to understand the reason why at least some Malay stocks of the population in the region have a strong bound to Rum and refer to this in various authentic textes we should have a consideration of their weltanschaaung. I assumed Turkish origin of few ruling elites at Malay sultanates such as Minangkabau, Malacca and Jambi Sultanates.

It is stressed that the genealogy of Bandahara Malacca in Sejarah Melayu is originally connected Turkish elements in India. The text refers to son of Nizam-ul Mulk Akar Shah, Iranian Saljuqi, as the grandfather of Bandahara. ${ }^{66}$ In regard to this, for instance, Minangkabau, which is geneologically bound to the Malay stock in the east, West Sumatra and the western coastal areas of the Malay Peninsula, possessed codes of adat (customary law) which exist to explain the origins of human world starting from Adam, and continues with "the geographical division of the world into the three empires of Rum, China and Menangkabowe, the first establishment of kingly power" ${ }^{67}$ This aspect of the usage is relevant inevitably for the consideration of political legitimacy referring to then globally mighty of Turkic state. $^{68}$

There is also an observation about how to claim sovereignty and mighty power of the Ottoman reflected in the attempt of a Javanese prince during the initial decade of the 16th century while the Portuegese targetted to invade the region, Trenggana, the Demak prince, initiated to prosetilyze the whole Jawa island in the middle of the century. The latter's attempt was evaluated as his being to be considered as a new Turkish sultan in the region. Further, the Demak army was also including some Turkish warrior group beyond the Acehnese, Tagalog and Champanese. ${ }^{69}$

\footnotetext{
62 Vladimir Braginsky (2015), "Introduction," p. 3.

${ }^{63}$ Christopher Shacke (2000), "Beyond Turk and Hindu: Crossing the Boundaries in Indo-Muslim Romance," in Beyond Turk and Hindu: Rethinking Religious Identities in Islamicate South Asia, Gainesville: University Press of Florida, p. 56.

${ }^{64}$ T. İskandar (1966), Bustanu's-Salatin, p. 40.

${ }^{65}$ T. İskandar (1966), Bustanu's-Salatin, p. 161. (The relevant account is as follow: “Pada suatu zaman bahwa sultan Muhammad jang kerajaan dalam negeri Rum itu sakit kepala dan sedjuk segala anggotanya. ... obatnya melainkan salitu'l kafur dan salitu't turab. Jani minyak kapud ran minyak tanah. "dengar chabar minyak kapud dan minyak tanah itu dibumi masjrik yang bernama negeri Atjeh Dar as -Salam itu. Djika demikian suruhkanlah dua orang rum seorang namanya Celebi Ahmad dan seorang Celebi Rldwan yang mengadap daku ini sertanya seratus orang Rum dan dibawanya sebuah kapal dengan segeranya ia pergi kenergi Atjeh Dar as Salam."

${ }^{66}$ G. E. Marrison (1955), "Persian Influences in Malay Life: 1280-1650," Journal of the Malaysian Branch of the Royal Asiatic Society, Vol. 28, Part I, no. 169 , p. 54.

${ }^{67}$ John Anderson (1839), Political and Commercial Considerations Relative to the Malayan Peninsula and the British Settlements in the Straits of Malacca, Vol. II, London: John Murray, p. 227. (Note: There is an arguement by referring to a manuscript which gives an explanation of Islamization of Minangkabauen people via Radja Roum. See: "Moelanja Igama Islam diketahoei di Minangkabau," Fadjar Islam, No. 15, Djoem'at 31 Januari 1930 / 1 Ramadhan 1348, Tahoen II, p. 333.

68 Vladimir Braginsky (2015), "Introduction," pp. 6-7.

69 A. H. Johns (1993), "Political Authority in Islam: Some Reflections Relevant to Indonesia," in Anthony Reid (ed.), The Making of An Islamic Political Discourse in Southeast Asia, Aristoc Press Pty, Centre of Southeast Asian Studies, Monash University, Clayton-Victoria, Australia, p. 92.
} 
Gayo, which is a sub-region, (kabupaten) in Aceh Province of the Republic of Indonesia, has an oral tradition referring to Negeri Rum as the root and connection of their socio-religious background. In this regard, a name, Genali, is cited as the first man was agrounded in a small island, say, Buntul Linge, in Sumatra Island. And the man married with the prince of Johor court and founded a community in the region which later on was named as the Principality of Linge or Lingga ${ }^{70}$ Thus, the genealogy of some principalities in Sumatra Island appears a unique example, such as Linge principality being legitimized by the reference to Rum.

This process was perhaps a sort of tradition in state courteous writing in the region. This is not to deny that the sultanates in the Malay world were in strong bound supported with communication channel, thus, was well- informed about their own individual relations with the Ottoman State. In regard to this, once the western colonial expansion realized gradually but in a determined way such as in Java and Sumatra Islands the rulers of the sultanates tried ambitiously to approach to the Ottoman court to get recognition as soon as getting any symbolic items such as flag, nişan etc. ${ }^{71}$

There is also a reference to legitimation during the era of Jambi Sultanate, which was located in the eastern part of Sumatra Island. According to the local accounts the Islamization process of Jambian folk initiated by an important descendant of the Turkish ruler who landed in Jambi coasts as a wealthy trader in the 15 th century. ${ }^{72}$ In addition to these, I wish to mention a reference to a small chamber in Delhi Sultanate which seems to be a sort of honour to the then sultan(s) or the sultanate to have this special section in the palace. ${ }^{73}$

\section{The Geographical Expansion of Turkic Groups in a Larger Spheres}

It can be arguable that the expansion of Turkic elements realized beyond the intervention of political powers or emerged into state structural adoptation by peaceful means or military offense. This is, in fact, a very unique process led by the Turkic elements throughout the history, who were members of a larger unit that intended to establish a political entity mirrored like a principality and a state. And this diffusion of the concept of Rum and other relevant titles seems to have happened in one way, say, the attempt of understanding of the origin of a particular social group in South and South East Asia was initiated by the people in these mentioned geographies.

Hence, in my reckoning, this groups of people might have been forced to mobilize around the Indian Ocean by the external forces happened by either political or military reasons or even natural reasons such as looking for worldly fortune and fame or intangible gain based on religious ideals. Highly probably that the commercial centres of gravity of the port cities in the initially western part of the Indian Ocean attracted the Rumis to conduct commercial activities.

Since the initial threats of the Portuguese in the Red Sea, the Ottoman court allowed some groups of people, in particular, Turcoman origin as voluntarily to take part in the military and navy establishment of the Mamluk Sultan. And some among these groups well equipped "adventurer-soldiers" who were called as Rumis by Arap and Indians. ${ }^{74}$ In regard to this, the report (lahiya) written by Selman Reis to the Ottoman court, as stated by İnalc1k, about taking measures to get upperhand of the Indian trade which was being dominated then by the Portuguese in the same region including southern Arabian Sea might have given result in the positive response some Rumi circles who either located in the Red Sea or later period left behind from the sea expeditions against the Portuguese. ${ }^{75}$

\footnotetext{
${ }^{70}$ M. J. Melalatoa (1982), Kebudayaan Gayo, Catatan Kedua, Seri Etnografi Indonesia, No. 1, Jakarta: PN Balai Pustaka, p. 36; John R. Rowen (1989), "Narrative Form and Political Incorporation: Changing Uses of History in Aceh, Indonesia," Society for Comparative Study of Society and History, Vol. 31, no. 4, p. 673.

${ }^{71}$ BOA, İ.HR.173.9431.3.1. (1276.C.04 - 29 December 1859); Holder Furber (1976), Rival Empires of Trade in the Orient: 1600-1800, Minneapolis: University of Minnesota Press, p. 86; Anthony Reid (1969), "Indonesian Diplomacy A Documentary Study of Atjehnese Foreign Policy in the Reign of Sultan Mahmud: 1870-4," JMBRAS, Volume XLII, Part 2, p. 80; Hamka (1977), Sejarah Umat Islam, (second printing), Singapura: Pustaka Nasional Pte. Ltd., p. 551. (Note: Hamka emphasises about the presents sent by the Ottomans: "Salah satu lambang kerajaan Minangkabau-Islam ialah sebuah cap raja Turki (bernama Thaghraai), masih disimpan ole anak cucunya di Pagaruyung.

72 Rachman Lukman (1983). Sejarah Perlawanan Terhadap Kolonialisme dan Imperialisme di Jambi, p. 7.

${ }^{73}$ A Handbook for Travelers in Indian and Pakistan, Burma and Ceylon (n.d.), sixteenth edition, London: John Murray, p. 275.

${ }^{74}$ Halil İnalc1k \& Donald Quataert (eds.) (2005), An Economic and Social History of The Ottoman Empire, Vol. I: 1300-1600, Fifth Printing, Cambridge: Cambridge University Press, p. 321.

${ }^{75}$ Halil İnalc1k (2014), "The Ottoman Economic Mind and Aspects of the Ottoman Economy," in Studies in the Economic History of the Middle East: From the rise of Islam to the present day, London: Routledge, p. 212. See for details: Şahabettin Tekindağ (1968), "Süveyş'de Türkler ve Selman Reis'in Arızası," pp. 77-80.
} 
Although the Rumi accounts implicitly connects Turks to distant geographies of the known world, here, I want to argue that the Turkic elements who appear to have mobilized by their own attempts in the adjacent geographies in the Indian Ocean, did not become united under any leadership cadre, acted in a form of considerable military or political power throughout their existence in the region.

Or at least it is not known that they had a strong connection with the epicentre of the Ottoman court to get orders and act on behalf of the Ottoman rulers. Instead, their existence, as individual and group entities, played a crucial role through their own decision making processes including by the nature of the things which forced them to act accordingly as well. Even during the mighty power of the Ottomans, it is not observed that the Ottomans became "a consistent sea power in its attempts in the Indian Ocean either in civil trade business or military work" ${ }^{76}$ On the other hand, it is highly probable that beyond their own intentional political initiative, the Rumis' mobility in transregional context might have prepared ground for their being well-percieved by the native societies, in particular the latter decades of the 19th century and beginning of the 20th century.

Departing from this argumentation, it is essential to constitute some questions. For instance, what were the triggering points that drove the Turkic elements dispersed into a larger geography stretching from the Arabian Sea to the Island of Ternate? What made the Rumis recognized by the native rulers and peoples in diverse geographies? In which scope did the Rumis have internal networks with each other in a larger scope of geography from the western coasts of the Indian Ocean to eastern borders and beyond of it?

I think one of the most obvious and rational answer to this is related to geographical influences. In particular, the historical and traditional trade routes allowed these Turkic groups to move from one port city to another following their own fate as travelling merchants. This process, at least, can be traced in early phase of the encountering of Turks with the Muslim nations and their conversion to Islam in Central Asia. ${ }^{77}$ On the other hand, if fairly said, the impact and influences, the scope and continuity of the existence and activities of the Turkic elements in the Indian Ocean hosting the exchange of a large variety of commercial goods, peoples from east, west and north, scholarly ideas and texts, are yet to yield any significant results of investigation.

According to some historical accounts written both by the native scholarly individuals or courts' narratives penned down anonymously, Western travellers and colonial office employees' reports and notes clarify that the terms Rum, Rumi and Turcoman expanded from the coastal area of Arabian Peninsula to the eastern end of the Archipelago. ${ }^{78}$ The existence of the Turkic elements in the whole Indian Ocean and partly beyond it is quite understable pertaining to some reasons. It is manifested that the phenomena of Rum and Rumi are relatively widespread and beyond these two concepts, the word Turcoman was mentioned as well. On the basis of the references, Turcoman is referred to mostly the semi-nomad Turkic groups in northern India, Persia and Southeastern Anatolia and northern Iraq and Syria. It is understood from the account of Inalc1k about the military group which took part in measures taken by the Mamluks against the Portuguese power in the Red Sea that the people called Turcoman were different from Rumis. In the mentioned account Emir Hüseyn commanding the Mamluk fleet is referred as Turcoman, while his army unit established by about 1500 Rumi mercenaries as Turks. ${ }^{79}$ But on the other hand, it is comprehended that Turcoman can also be called Rumi by some other nations such as Arabs and Indians. ${ }^{80}$

Here the historical process can be summarily mentioned how the Turkic groups affiliated to the nations interconnected through sustainable maritime commercial affairs in the adjacent regions to the Indian Ocean, including the Eastern Mediterranean. The relatively early period between the 11th and 14th

\footnotetext{
${ }^{76}$ Salih Özbaran (2007), “Osmanlılar ve Deniz: 16. Yüzyıl Hint Okyanusu Bağlamında Yeniden Bakış,” in Özlem Kumrular (ed.), Türkler ve Deniz, İstanbul: Kitap Yayınevi, p. 53.

${ }^{77}$ Iqtidar Husain Siddiqi (1994), “The Turks and Their Migration to Central Asia and India,” pp. 177-178.

${ }^{78}$ Turcoman (Türkmen) is a group of Turk considered as a classification under the Oghuz Turks. See: Scott Levi (2007). "Turks and Tajiks in Central Asian History," in Jeff Sahadeo \& Russell Zanca (eds.), Everday Life in Central Asia Past and Present, Bloomington: Indiana University Press, p. 15 .

${ }^{79}$ Halil İnalc1k \& Donald Quataert (eds.) (2005), An Economic and Social History of The Ottoman Empire, p. 319. (Note: The word of Turcoman was first time used by Maksidi in the end of the 10th century during the Islamization process of Oghuz Turks. See: İbn Fazlan (1975), İbn Fazlan Seyahatnamesi: Onuncu Asırda Türkistan'da bir İslam Seyyahı, Ramazan Şeşen (trans.), İstanbul: Bedir Yayınevi, p. 97.

${ }^{80}$ Halil İnalc1k \& Donald Quataert (eds.) (2005), An Economic and Social History of The Ottoman Empire, p. 321.
} 
centuries, the Islamic world fundamentally under the hegemony of Turkic and Mongol control except the Western African shores and the Malay Archipelago. ${ }^{81}$

In the course of time, there was a significant intra-regional commerce emerged in the larger coastal borders adjacent to the Indian Ocean and especially towards the East Indies, say, the Archipelago before and during the colonial periods. Interestingly, these relevant references had earlier emerged before the arrival of the western European maritime nations into the Indian Ocean. As Salih Özbaran argues that the ancient commercial life between the Mediterranean and the mentioned ocean commenced even during pre-Islamic period. Without diminishing the importance of the Saljuqi Turks presence and perhaps some other minor Turkic elements living in borders to the Indian Ocean, the Ottomans gradually but actively engaged in the Arabian Sea, the Persian Gulf. ${ }^{82}$ And various nationalities took part in the same opulent commercial life particularly through the vessels carrying large amount of eastern products to the ports in the Red Sea belonged to the Indian, Arab and Turkic origin seamen and traders. $^{83}$

\section{Some Ideas about the Mobilization of Rumis}

In addition, Turkish principalities and sultanates first established in Indo-Persian region and later on in the geography, contemporarily known as Middle East including Egypt and Arabian Peninsula served to be a pushing factor for at least some of the Turkic groups which highly probably included non-Muslim subjects to disperse and took part in commercial and militarily activities throughout the Indian Ocean.

These features can also be applied to the other groups from distinct nationalities such as Persians, Arabians, Armenians etc. who became subjects of intra-regional mobilization in the same direction to a lesser or larger extent. Because of this reason, the flourishing port cities which were called by these nationalities favourable for settlement that allowed the emergence of cosmopolitan commercial hubs with their rich hinterlands and built up parts of global trade network established sustainably throughout the centuries.

No doubt that the expansion of the concept of Rum in larger Malay world is aligned with two distinguished events or developments. If I need to put them in order, the initial one, I would assert, the dimension of religion, say, Islam. Though islamization process is assumed to have commenced in very earliest centuries of the Hijri year, the establishment of onthological and existential attempts would have taken place in a bit later period, in particular, with the commencing of the written sources such as Hikayat Raja Raja Pasai.

This process witnessed in most extent the gradual increase of Turkic state establishments such as Ghaznawi, Saljuqi, Ottoman in a larger parts of West Asia from the borders of Afghanistan till the eastern Europe. Without eliminating the importance of the Sacred Land for the newly converted Malay principalities, while the power circulation moved from the centre of Islam, say, Hijaz to capital cities of the dynasties such as Baghdat, Konya, Constantinople, the Malay world proceeded to acquire political legitimation from the latter ones. Another stage is perhaps relevant in conjunction with the adjunct non-Muslim kingdoms in the region of the Straits of Malacca, such as Srivijawa and Majapahit existed from the 7th century till the first part of the 16th century.

It is perceived that the connectivity of the larger Turkic nations with the Malay world goes back to early centuries such as 14th century. This relatively early date is relevant, no doubt, with probable interaction with the Great Saljuqi State till the borders of the Indian Ocean through either Indian or Persian port cities. While we consider the formal state establishment of the Saljuqi, it is not necessary to assert that the central governmental mechanization played a frontier role. Instead, it is more logical to think about the individual social groups such as traders, scholars, artisans, soldiers being subjects of the Saljuqi State, who are known historically to have mobilized through various reasons.

\footnotetext{
${ }^{81}$ Metin Kunt (1984), “The Later Muslim Empires: Ottomans, Safavids, Mughals,” p. 115.

${ }^{82}$ Salih Özbaran (1972), "The Ottoman Turks and The Portuguese in the Persian Gulf, 1534-1581," p. 45. (Note: This intra-continental commercial activities in pre-Christian era is dealt in the relevant book of the present writer. See: Mehmet Özay (2018), Açe Darüsselam Sultanlı̆̆l: Íslam öncesi dönemden 20. yüzyıl başlarına kadar Açe tarihi, İstanbul: Fatih Sultan Mehmet Vakıf Üniversitesi Yayınları, pp. 3965.

${ }^{83}$ C. R. Boxer (1996), “A Note on Portuguese Reactions to the Revival of the Red Sea Spice Trade and the Rise of atjeh: 1540-1600," in M. N. Pearson (ed.), Spices in the Indian Ocean World, Variorum, p. 281.
} 
It should be remembered here that the relevant port citizens and principalities were also demanding qualified individuals to improve their administrative and military establishments. Thus, it is logical to assert that it is also highly possible that for instance, an individual occupied few professions such as, being both a soldier and a merchant; or as a scholar involved in small scale trade interactions to survive materially, as well disseminated their knowledge and conducted Islamic open activities for non-Muslim dwelled in cosmopolitan port societies at the same time.

Beyond this quite early period, nearly after 200 years, the Portuguese sources refer to some relevant data and information about Turkic existence in the Malay Archipelago commencing from the initial years of the 16th century. For instance, it is accounted that there were some distinct Muslim nationalities including Turks, Rumes during the attack of the Portuguese to the city of Malacca. ${ }^{84}$

But it is also interesting to inquire what sort of self-mobilization processes and through which social groups participated in cross border and inter-community establishments in the adjacent regions of the Indian Ocean and the Archipelago through two centuries. I may argue that the relevant information might exist in some sources written in local languages which have yet to be exposed to academic world.

Some individual travellers' accounts also refer to some Turkic groups in the region. For instance, it is understood that Bolognese traveller Ludovico di Varthema encountered some 400 Turkish merchants residing in Diu. In addition, Cemal Kafadar making a comment on this issue argues that these 400 people belong to a particular language group, say, Turkish one, because this city is also called Diu as Rumi Port (Diu Bander-er-Rumi/Diu the Port of the Rum). ${ }^{85}$

Kafadar refers to Calicut, another port city in the Southeastern region, hosting Muslim merchants among whom there was a group of Turkic background with their head. ${ }^{86}$ It is safe to assume that the former warriors after settling in the region involved commerce which might have been an opportunity and impulse for their money-making in the region. Or probably they may have functioned as basically and purely adventurous individuals in easterns seas. But no doubt that this sample proves, to some extent, the present writer's argumentation mentioned earlier about the role and function of the Rumis as both warrior and trader.

The junction of the head of the Persian Gulf and the Northwestern part of India which was acknowledged as "the gateway to India" (Farj al-Hind) ${ }^{87}$ known to various distinct nations such as Persian, Turks, Arabs hosted a heteregonous metropolitan centres, in particular, the Gujarat region with its ports cities of Surat and Diu. Here as it is observed by some travellers that this region comprises members of nations of West Asianist such as Armenians, Jews and including the Turkish ones. ${ }^{88}$ In regard to this, Ranir, relatively a smallar town than the latter ones, attracted Malay and Turkish merchants in the first half of the 16th century, before the militarily influence and invasion by the Portuguese ${ }^{89}$ Though there might be a sort of exaggeration, it is mentioned that the larger section of the population in Goa city belonged to Turkish elements which seem to have attracted the attention of D' Albuquerque, the Portuguese commander captain, to capture and control the commercial activities. ${ }^{90}$

\footnotetext{
84 'D'Albuquerque in Malacca', The Portuguese Period, JMBRAS, Vol. XIII, Part I, March, 1935, Singapore, p. 62; Armando Cortesao (ed.) (1990), The Suma Oriental Of Tome Pires, New Delhi: Asian Educational Services, p. 268; M. J. Pintado (ed.) (1993), Portuguese Documents on Malacca, Vol. 1: 1509-1511, Kuala Lumpur: National Archieves of Malaysia, p. 317; Frederick Charles Danvers (1966), The Portuguese in India: Being a History of the Rise and Decline of Their Eastern Empire, II. Bask1, Vol. I, London: Frank Cass, p. 223.

${ }^{85}$ George Percy Badger (1863), The Travels of Ludovico di Varthema, London: Printed for the Hakluyt Society, p. xlix; Cemal Kafadar (1996), "A Death in Venice (1575): Anatolian Muslim Merchants Trading in the Serenissima," in Sanjay Subrahmanyam (ed.), Merchant Networks in the Early Modern World, Aldershot: Varioum, p. 100.

${ }^{86}$ Cemal Kafadar (1996), “A Death in Venice (1575): Anatolian Muslim Merchants Trading in the Serenissima,” p. 100.

${ }^{87}$ S. M. Yusuf (1970), Studies in Islamic History and Culture, Lahore: Institute of Islamic Culture, p. 158.

${ }^{88}$ John Harris (MDCCV) (1705), "The Voyages and Travels of Mr. John Albert de Mandelslo Into the East-Indies In the Years 1638, 1639, 1640 Containing and Particular Description of the Empire of the Great Moghul," in A Complete Collection of Voyages and Travels, (Navigantium atque Itinerantium Bibliotheca), Vol. II, London: Printed for Thomas Bennet, p. 113; Lakshmi Subramanian (1999), "Introduction," in The French East India Company and the Trade of the Indian Ocean, Calcutta: Munshiram Manoharlal, p. xvii. (Note: Seydi Ali Reis accounts in his reputable book that there were some Rumi aşiklar who had experiences travilling to China. Through their suggestion the Chinese ruler allowed the sermon during Id'ul Fitr (or Id'ul Adha) called upon to the name of Padişah-1 Rum. See: Seydi Ali Reis (n.d.), Mir'at-ül Memalik: Ülkelerin Aynası, Baskıya Hazırlayan: Necdet Akyıldız, Tercüman 1001 Temel Eser, İstanbul, pp. 75-76.

${ }^{89}$ Azyumardi Azra (2004), The Origins of Islamic Reformism In Southeast Asia: Networks of Middle Eastern and Malay-Indonesian 'Ulama' In The Seventeenth and Eighteenth Centuries, Allen\&Unwin ve University of Hawaii Press Honolulu, p. 55. (Note: Ranir is a subdistrict of Gujarat Province in contemporary Indian administrative system).

${ }^{90}$ M. N. Pearson (1979), “Across the Black Water Indian Seafarers in the Sixteenth Century," in 'The Indian Ocean in Focus' International Conference on Indian Ocean Studies, Section III The History of Commercial Exchange\&Maritime Transport, Perth Western Australia, p. 4.
} 
Since the geographical location of Gujarat which is in the border and having a strategic connection both in land and sea ways between Persian and Indian lands, almost all the nations in West Asia could be encountered there. And these nations, it seems including the Turkic ones as well, set off their travels through this port city to the Archipelago. As remarked in a travellers' anthology, some people looking similar to Turks by wearing Turkish clothes might have belonged to Turkic groups. And their involvement into commerce in the port cities in Sumatra supports the idea of these groups of people had various engagements in their life. ${ }^{91}$

Gujarat was a crucial destination for those trade vessels from the Archipelago, especially the ones from Sumatra Island. And this intra-regional network between North-western India, Malay Peninsula and the Archipelago caused more traders and seamen from distinct nationalities to have become entrepreneurs on the course of time. Once the city of Malacca emerged as the most important emperium in the Straits of Malacca in the 15th century, the mobility of the traders from all relevant countries and region including the Turkic elements increased gradually. And these elements including eastern Africanese, Egyptian, Persian, Armenian and Turks among which the latter seem to have classified as Rum, Turcoman, not only involved the commercial activities but also, at least, some of them preferred to settle in this emperium. ${ }^{92}$

And this region was also relatively known in Ottoman circles owing to the few sea expeditions conducted in the first part of the 16th century. And it is safely argued that some of the sea warriors settled and got some positions in the courts of the rulers of the petty states after these expeditions. ${ }^{93}$ And in this context, even some individual Rumis such as, Melique Ayaz were appointed as the rulers of the ports which might have been equal to shahbandarship. This is not to deny that the roles of these individuals were unique in terms of both controlling the commercial activities and creating a military force against, in particular, the Portuguese who were actively engaging the region's trade business. ${ }^{94}$

It is worth here mentioning even some Turkic groups increased until the leadership position in few places such as Bengal. For intance, Fatimi asserts that Bengal was under the rulership mostly by Turkish slave groups (mamluks) which had a continuity till the establishment of the sovereignty of the Moghuls in the region. ${ }^{95}$

The trace of the sea lanes throughout the West bank of Indian Peninsula via Malacca Strait to the city of Malacca allows us to detect the existence of the Turkic elements in port cities. According to the reports, for instance the one penned down by Tome Pires helps to witness Turkic elements among others belonging to distinct nationalities. ${ }^{96}$ For instance, Pires observed that the migration of the regional traders from the city of Malacca to Pasai, a port city in northern coast of Sumatra Island and later on to the capital city of the Sultanate of Aceh Darussalam, which would have been recognized as the new political and commercial center of the region, after the former was occupied by the Portuguese forces. According to his accounts there were also Turkic groups who are named as Rumes and Turks among the other nationalities such as Bengali, Arabs, Persian, Gujarati, Kling, Malay, Jawanese and Siamese at the very beginning of the 16th century. ${ }^{97}$

Coromandel, in the continuity of the western coastal area took a significant place where some Turkic people were also encountered as it is understood in some references. This particular port city like the others even before the Portuguese had significant trade relations with Sumatra Island, which is the nearest island located being adjacent to the Indian Ocean. And the traders from this particular region

\footnotetext{
${ }^{91}$ Anthony Reid (ed.) (1995), Witnesses to Sumatra: A Travellers' Anthology, Kuala Lumpur: Oxford University Press, p. 63.

92 Armando Cortesao (ed.) (1990), The Suma Oriental Of Tome Pires, p. 46; Muhammad Haji Salleh (1997), "Pengenalan," in Sulalat alSalatin, (Dikaji dan diperkenalkan), Kuala Lumpur: Yayasan Karyawan dan Dewan Bahasa dan Pustaka, p. xxxiii.

${ }_{93}$ Nevzat Köseoğlu (1991), Türk Dünyası Tarihi ve Türk Medeniyeti Üzerine Düşünceler, İstanbul: Ötüken Yayınları, p. 237.

94 Frederick Charles Danvers (1966), The Portuguese in India, p. 140; Yılmaz Öztuna (1983), Büyük Türkiye Tarihi -Başlangıcından Zamanımıza Kadar-, İstanbul: Ötüken Yayınevi, p. 76.

95 Sayyid Qudratullah Fatimi (n.d.), Islam in Malaya: The Historical Perspective, Part I (Visiting professor in Urdu\&Pakistani Studies University of Malaya, Singapore), Leiden Library Special Collections: Or 637 (145), p. 18.

${ }^{96}$ Armando Cortesao (ed.) (1990), The Suma Oriental Of Tome Pires, p. 46.

97 Armando Cortesao (ed.) (1990), The Suma Oriental Of Tome Pires, p. 142; Arum Komar Das Gupta (1993), "Iskandar Muda and The Europeans," in Ali Hasjmy (ed.), Sejarah Masuk Dan Berkembangnay Islam di Indonesia, Edisi Ketiga, Ptalmaarif, pp. 43-44; Dianne Lewis (1995), Jan Compagnie in the Straits of Malacca 1641-1795, Athens: Ohio University Center for International Studies Center, Southeast Asia Series, No. 96, p. 128.
} 
are called as Keling. ${ }^{98}$ This account is more inspirative so as to understand the existence of similar groups in more distant geographies such as Sumatra Island, Malay Peninsula and even Java Island. I should remind here that somewhere in this article when configuring connection of Jambi with its Turkic background on the basis of Hikayat Negeri Jambi, ${ }^{99}$ a great merchant Turkish ancestor which is highlighted as reference might have been someone ventured from port cities of the western coast of India.

As likely Portuguese sources, Dutch accounts witness over the presence of a Turkish merchant among various other nations such as Bengali, Chinese, Persian, Arabs and Gujarati intermingled in Bantam port in the very initial stage of their expedition into the Archipelago in the last years of the 16th century. ${ }^{100}$

As a unique example a Jawa text from the 19th century refers to a Turkish princess who seems to had been in Penang Island and was rumoured to assist a Jawanese prince while he was in exile there. It is also perceived that she was also with a Turkish escort during her whole travel in the East. ${ }^{101}$

All these above-mentioned references are based on the acquired identity of the seafarers from the Asia Minor who is understood to have claimed themselves as a member of the land of Rum and a subject of the ruler of Rum which means the Ottoman ruler(s). ${ }^{102}$ But at the same time, it is critical to understand the meaning of Rum for the indigenous people and the ruling elite of the relevant geographies. Since the word 'Ottoman' was not indeed familiar as much as the term of Rum in the regions of Indian Ocean and the Archipelago. Probably the majority of the written documents produced either by native landers or the travellers and the western colonial circles did not mention the name of Ottoman, instead referring more to the terms of Rum and Rumi.

Though as seen in the above-mentioned summary quoted from the regional and western sources, it is not easy to determine precisely when the Turkic elements initiated their involvement into Indian Ocean. It can be safely argued that beyond the Ottoman subjects mobilized through the port cities in the Red Sea, some other Turkic elements in Northwestern region or the port cities and towns in Basra Bay might have taken parts in intraregional commercial activities and become mercenaries in the principalities in the relevant regions. The latter case makes us consider, in particular, that the political and cultural dominancy of various Turkic elements in Northwestern part of India caused them to set off voyages via the ocean to reach the Archipelago to acquire military and commercial advantages. In addition, the religious cause pertaining to proselytization efforts should not be disregarded in the early centuries such as 12th and 13th century. Since some accounts in Aceh region refer strongly to the existence of Turkic elements in early period, coming from abroad and settled in Kampung Pande to establish a principality in the coastal area of contemporary Banda Aceh in northern tip of Sumatra Island. ${ }^{103}$ In this regard, reflections of the Turkic language and cultural aspects among the native societies such as Gujarat,

\footnotetext{
${ }^{98}$ Sanjay Subrahmanyam (1997), "The Coromandel Malacca Trade in the Sixteenth Century: A Study of its Evolving," in Om Prakash (ed.), European Commercial Expansion in Early Modern Asia, Volume 10, Aldershot: Varioum, p. 46.

${ }^{99}$ This issue is also highlighted in different aspect in particular referring to Turks during the early Islamization process in 15 th century in some dissertations conducted at Jambi Province, arguing that the late 15th century Islamization process initiated by a Turkic trader who is asserted to be descendant of a Turkish ruler. See: Lukman, Hajar, Zaituni \& M. Nazir Munawir (1992-1993), Sejarah Perlawanan Terhadap Kolonialisme dan Imperialisme di Jambi, Departemen Pendidikan dan Kebudayaan Proyek Inventarisasi dan Dokumentasi Sejarah Nasional, pp. $7 \& 20$.

${ }^{100}$ E. S. De Klerck (1938), History of the Netherlands East Indies, Vol. I, Rotterdam: W. L.\& J. Brusse N. V., p. 160; J. C. Van Leur (1967), Indonesian Trade and Society: Essays in Asian Social and Economic History, W. Van Hoeve Publishers Ltd-The Hague, pp. 3-4 \& 162; Cemal Kafadar (1996). "A Death in Venice (1575)," p. 97.

${ }^{101}$ Peter Carey (ed.) (1992), The British in Java 1811-1816: A Javanese Account, (British Library Additional Manuscript 12330) (Babad Bedhah ing Ngayogyakarta), The British Academy, Oxford University Press, p. 149.

102 Christine Isom-Verhaaren (2014). "Was there Room in Rum for Corsairs?," p. 236.

103 Tuanku Abdul Jalil (1980), "Sebab Aceh Dinamakan Serambi Mekkah," Seminar Sejarah Masuk Dan Berkembangnya Islam Di Aceh Dan Nusantara, Aceh Timur, 25-30 September 1980, p. 3; Ibrahim Alfian (2006), "Islam Dan Kerajaan Aceh Darussalam," in Taufik Abdullah (ed.), Sejarah Dan Dialog Peradaban, Jakarta: LIPI Press, p. 238; Ibrahim Alfian (2005), "Kerajaan Aceh Darussalam: Sebuah Wacana Singkat," Prosiding Seminar Antrabangsa Kesultanan Melayu Nusantara: Sejarah dan Warisan, 8-11 Mei, Kuantan Pahang Darul Makmur, Lembaga Muzium Negeri Pahang dan Institute Alam \& Tamadun Melayu UKM, Bangi, pp. 319-415. (Note: The muballigh who arrived in the northern tip of Sumatra Island from the Hormuz region during the epoch of the Abbasid Dynasty, are acknowledged as Saljuqi Turks. (See: Affan Seljuq (1980), "Relations Between The Ottoman Empire and the Muslim Kingdoms in the Malay-Indonesian Archiapeloge," Der Islam, Vol. 57, p. 303.) In addition, Metin İnegöllüoğlu, the Turkish ambassador to Jakarta in the years between 1986-1989, observed personally and collected data from the local informants during his visit to Kampung Pande and penned down his ideas about this issue. (See: Metin İnegöllüoğlu (1998), Asya-Pasifik'te Türk İzleri, Manisa: Celal Bayar Üniversitesi Yayınları.) I had a similar observation and met some people who claimed their ancestral relations to Turks. For instance, I interviewed a 85 year-old lady called Cut Keumala in Bitai-Emperoum, in Banda Aceh in 2005. She expressed that her ancestors coming from Rum and they were Turks. Though there had been a genealogy, it was washed away unfortunately during the tsunami, 2004.
} 
Bengal, Malaya, Telagu and Tamil can be considered. And no doubt to be able to perceive the scope of this influence and reflections there should be detailed studies in each regions of India. ${ }^{104}$

Hence, at least it can be arguable that starting from Saljuqi Turks, there were mobilization of some individuals and groups in the border of the Indian Ocean. In particular, coastal area of Oman which was one of the hubs in commercial activities between West and East became a subject of expeditions by various warrior groups. And along the two hundred years, between 893 and 1063 in Gregorian calendar, this region became a target by not only Turks but also Persians, Karmatians, Dailamities, and Turcomans. ${ }^{105}$ On the other hand, the other aspect of the term Turk should not be forgotten while it is used, in particular, in a region like India which hosted variety of ethnic structures claiming to be attributed to Turkish nation. In this respect, it is quite interesting to find that the Arabs designated the word Rum, 'was a conventional' usage, and it is understood as "more correctly, Circassians, Afghans, and Persians". 106

\section{The Power Relations and Establishment of Political Legitimacy}

The first is the mighty power of the Ottoman State pertaining to its military capacity and capability which was well started to be considered as a world power, in particular, by conquering Constantinople. The other is the Ottomans' acquired the protection of the Holy Land commencing from the end of the second decade of the 16th century. This justifies that the former development is a fundamental process for the Ottomans to inherit the title of Rum where state was named 'The Sultanate of Rum' and the sultans were also referred or acquired honorofic title such as 'the sultan of Rum' accordingly. On the other hand, the latter caused its power and fame to become dominant in the neighbouring geographies of the Indian Ocean. ${ }^{107}$

What is understood from the above mentioned processes is that the Rumis could not be perceived as the secondary players because of the fact of recruitment as mercenaries or to put it bluntly, an inferiority enclaves of races to the rulers of the petty states. Instead, the Rumis must have taken some crucial steps to be play makers in these geographies offering their services on the basis of their capacities and capabilities in military skills and productivity. On the other hand, considering of not only war times but also perhaps mostly the peaceful periods in the region, it is highly probably that the Rumis must have taken part in commercial activities for their own survival. This is a logical process since the Rumis were not recruited to serve to the native rulers on salary-based, but on the basis of plunder which was basically their material benefit after the attacks or wars.

In regard to all discourse, it is logical that the Rumis as mercenaries to have looked after commercial elements to exist in relevant eastern port cities. Even it is arguable enough that the Rumis could have exerted some joint business venture among themselves or similar social groups from various nations and acted accordingly intra-cities commercial activities in peaceful times. If some relevant data is found about these sorts of interactions among the various groups from distinct nations, it would definetly cause to reconsider the history of the adjacent regions to the Indian Ocean.

I think the references of the existence of Turkic groups even in relatively early era such as in 1502 during the visit of Vasco da Gama must have been relevant with the Turkic groups commerical activities with other groups. And the Portuguese tried to enforce the local rulers through some agreements not to allow Turkish trade vessels to the Calicut port. ${ }^{108}$

Rumis could have been part of the international commerce in the various port cities in the region. For instance, it is observed that there was a Turkish community aligned with others such as Indians, Chinese, Jawanese and Malays in the cosmopolit city of Malacca during the early stage of the Portuguese

\footnotetext{
104 Akmal Ayyubi (1960), “Hint Kültürü Üzerinde Müslüman Türk Tesirleri,” in İslam Tetkikleri Enstitüsü Dergisi, Vol. III, 1-2 Kısım, İstanbul: İ̈̈EF Yayınları, p. 209.

105 V. D. Divekar (1979), "Maritime Trading Settlements in the Arabian Sea Region Up To 1500 A.D.," in 'The Indian Ocean in Focus' International Conference on Indian Ocean Studies, Section III The History of Commercial Exchange \& Maritime Transport, Perth Western Australia, p. 10.

${ }^{106}$ George Percy Badger (1863), The Travels of Ludovico di Varthema, p. xlix.

107 F. R. C. Bagley (1969), "The Ottoman Empire to 1774," in The Muslim World: A Historical Survey, Part III: The Last Great Muslim Empires, Leiden: E. J. Brill, p. 50 (Note: A similar expression of 'Sultan Rum' is mentioned by Nuru'd-din ar-Raniri in his Bustanu's Salatin. See: T. Iskandar (1966), Bustanu's-Salatin, p. 31.

${ }^{108}$ Muhammad Yakub Mughul (1987), Kanuni Devri, Ankara: Kültür ve Turizm Bakanlığı Yayınları, p. 23.
} 
occupation. ${ }^{109}$ In this respect, the existence of the Turkic groups as mercenaries was not only connected with the native rulers but also western powers having involvement and engagement in some regions border to the Indian Ocean. For instance, the Rums of Ormus (Hurmuz) were referred to their host port city and it is understood that they gave a military support to the British in western Indian in around the early decades of the 17 th century. ${ }^{110}$ In addition, on the basis of some sources it is understood that Turkish elements also played a role in commercial business particulary silk trade in the region. ${ }^{11}$

Turkic ascendancy within the political and military life of Islam was the result of the Arab practice of using slave-soldiers as bodyguards. Rumis were recruited on the basis of mercenaries in eastern geographies particularly in Western and North-western coastal principalities of India. I assume that the concept of mencenary was regarded as the continuity of the practice of slave-soldiers in earlier periods such as the early Arab Muslim dynasties functionalized owing to the qualification and expertization of Rumis in various fields. ${ }^{112}$

And probably the latest example of this sort of recruitment appeared in Bone ruled by Bugis to employ a group of Turkish military personnel against the incursion of the colonial Dutch military power. ${ }^{113}$ It is also encountered that though few individuals' names mentioned by name in the sources there might have been some more Rumis took part in the wars between the regional powers. In regard to this, there was an Ottoman captain called Murat Reis in the army of the Sultanate of Aceh Darussalam against the Johor state in Malacca Strait in 1539. ${ }^{114}$

\section{Militarily Aspect of Rumis}

It is observed the existence and references of the term Rum and some other relevant names in adjacent geographies to the Indian Ocean, say, from the Arabian Peninsula till far eastern islands like Ternate, which might be regarded as the Islamic extremity of the Eastern region, in essentially starting from the beginning of the 16th century onwards. This process led by the demanding of the Rumis (Turkic mercenaries) by the native rulers in their struggle against, in particular, the Portuguese invasions in the port cities. Since the Rumis as strong soldiers, capable gun founders played prominent roles. ${ }^{115}$ As the historical processes are scrutinized accordingly including even the developments in the late decades of the 19th century and initial decades of the 20th century, it is safely argued that the image and perception of Turks cannot be separately understood from the above-mentioned long duree basis.

Admittedly, terms like Turk, Turcoman, Rum, Rumi are referred to same group of people who are no doubt considered as warriors either voluntairly affiliated some city states or recruited as mercenaries. In terms of this, in case of considering this group the one dealing with warriorship, it is believed that the Turkic groups acquired the artizanship from the initiators of the canon-makers and mercenaries who were the leading group in the army as seen in the wars of the early modern era of the Ottoman realm and expanded to the eastern geographies. ${ }^{116}$

\footnotetext{
${ }^{109}$ F. J. Moorhbad (1957), A History of Malaya and Her Neighbours, Volume One, London: Longmans, p. 188.

110 John Harris (MDCCV) (1705), "The Voyages and Travels of Mr. John Albert de Mandelslo," p. 181. (Note: There is also a reference to the existence of Rumis in Hormus in the account of the Portuguese. During the Portuguese being actively in engagement in the region during the early 16th century, the ruler of al-Hasa (Lahsa) ordered a vessel with oars to be build by the Turks. See: Salih Özbaran (1972), "The Ottoman Turks and The Portuguese in the Persian Gulf, 1534-1581," p. 47. (Note: A similar account is encountered -It is referred to a 19th century case- while the British colonial rule was intervening the Negeri Sembilan politics in Malaya, mercenaries from different nations including Turkish ones were functionalized as helper to a disputing party led by Sayyid Abd al-Rahman al-Qadri. See: Mohemad Redzuan Othman (1997), "The Malay Peninsula," in Ulrike Freitag \& William G. Clarence-Smith (eds.), Hadhrami Traders, Scholars and Statesmen In The Indian Ocean, 1750s-1960s, Ledien: Brill, p. 91.

111 P. A. Leupe (1988), "Letter Transport Overland to the Indies by the East India Company,” in M. A. P. Meilink-Roelofsz, M. E. Van Opstall \& G. J. Schutte (eds.), Dutch Authors on Asian History: A Selection of Dutch Historiography on the Verenigde Oostindische Compagnie, Dordrecht-Holland: Foris Publications, p. 89.

${ }^{112}$ Lawrence D. Higgins (1994a), “Turkic Empire,” in Franklin D. Margiotta (ed.), Brassey's Encyclopedia of Military History and Biography, Washington: Brassey's, p. 1006.

${ }_{113}$ William Clarence-Smith (2010), "South-east Asia and China to 1910," in Francis Robinson (ed.), The New Cambridge History of Islam, The Islamic World in the Age of Western Dominance, Vol. 5, Cambridge: Cambridge University Press, p. 266.

${ }^{114}$ Raden Hoesein Djajadiningrat (1982/83), Kesultanan Aceh, Teuku Hamid (trans.), Departemen Pendidikan dan Kebudayaan Proyek Pengembangan Permuseuman Daerah Istimewa Aceh, pp. 32-33; Fernao Mendes Pinto (1989), The Travels of Mendes Pinto, Rebecca D. Catz (ed.), Chicago: The University of Chicago Press, p. 55.

115 Halil İnalc1k \& Donald Quataert (eds.) (2005), An Economic and Social History of The Ottoman Empire, p. 321.

${ }^{116}$ Lawrence D. Higgins (1994b), ”Ottoman Empire," p. 751.
} 
Rumis as seen in general accounts are referred to be military personnel. In this regard, Rumis were as members of Ottoman military cruise and they are also referred as individuals or privates in another categorization. I may give an example for the first category from the Hadım Süleyman Paşa's military attempt in Diu in 1538. Fevzi Kurtoğlu states, referring to an authentic text pertaining to Diu expedition in Topkapı Palace Archive, indirectly that there are soldiers named as "Rumi Yiğitleri". ${ }^{117}$

It is understood that military service was a major task of the Rumis in various port cities and palaces. Since their qualification as soldiers they were hired as mercenaries in the armies of various dynasties. The preferences presented that they werenot only mere soldiers but also presided commanding position, as seen in the sample of the mid of the sixteenth century. For instance, Aslan Rumi (Imad-ul-Mulk) was appointed as the commander of the foreign unit including distinct nationalities such as soldiers from Eastern Africa (Habshi), Persian and Turks as well in Gujarat. We see the Rumis as mercenaries in various armies of the distinct eastern courts such as Gujarat, ${ }^{118}$ Even some was recordedas expert of cannon makers in some petty states which seem to have encountered in particular, western colonial powers and recruited these Rumis to tackle the weaknesses in that indigenous armies.

Further, it can be emphasized that among these Rumis might have been some deserters for some reasons from their own military attachment in relevant eras such as during the expeditions of the Ottoman navy in western India. The reasons, as observed among the Portuguese deserters in the early decades of the 16th century, could have been personal interest to be richer and gaining fame serving for the native palaces. ${ }^{119}$

On the other hand, it should be kept in mind that the sources mention the Rumis' existence in Northeastern India, in particular, Diu Island before the Ottomans' expansion in southern Arabia and also during the famous Diu expedition in $1538 .{ }^{120}$

It is also a must to consider some individuals cases relevant to Turkic elements as mercenaries recruited by some Indian principalities. For instance, Hüseyin Pasha, Governor of Basra, refuged politically to Cihangir (1658-1707) and became a commander of a larger unit of army of five thousand soldiers under him. After a while, a similar case emerged when Yahya Pasha, taken the governorship of Basra after Hüseyin, followed the steps of Hüseyin Pasha and refuged himself to Cihangir in $1671 .{ }^{121}$

On the other hand, geographical origin of these people gives an impression that they might mobilize independently on the basis of various reasons. In regard to this, I assert that Turcoman settled in various geographies such as Syria, Iraq, and also in central Asia. ${ }^{122}$ In addition, Rum and Rumi are terms which have a direct connection to Asia Minor, the individuals or relatively small group of people.

\section{Religious Scholars}

Rumi in the field of scholarly world is commonly used as title added to the name of particular religious scholars who settled originally in Anatolia, descendants or some parts of this Asia. This usage also is encountered in some part of the Archipelago.

These similar references in geographical connotation to Rum are encountered in the biographies of scholars from various faculties of science throughout the centuries. Idris-i Bitlisi, Davud Dede, Hüsameddin Efendi, and Arab Hakim were among the ones who were addressed as Rum as related to the geographical origins. In brief, these individuals as mentioned below, are recognized the distinguished ones who moved from eastern regions to Rum (Anatolia). For instance, İdris-i Bitlisi, who was the son of Hüsameddin Bitlisi, worked for Uzun Hasan in Iran. It is also mentioned that he migrated to Rum from Safavid State. Davud Dede came with Ali Mest from Buchara to Rum during the era of

\footnotetext{
${ }^{117}$ Fevzi Kurtoğlu (1940), “Hadım Süleyman Paşa’nın Mektupları ve Belgradın Muhasara Planı,” Belleten, Cilt IV, Türk Tarih Kurum, Ankara, Türk Tarih Kurumu Basımevi, p. 71.

${ }^{118}$ M. S. Commissariat (1921-1923), “A Brief History of the Gujarat Saltanat,” The Journal of the Bombay Branch of the Royal Asiatic Society, Vol. XXVI, p. 102.

${ }^{119}$ Sanjay Subrahmanyam (1997), “The Coromandel Malacca Trade in the Sixteenth Century,” p. 48.

${ }^{120}$ George Percy Badger (1863), The Travels of Ludovico di Varthema, p. xlix.

${ }^{121}$ Hikmet Bayur (1950), "Osmanlı Padișahı II. Süleyman'ın Gurkanlı Padișahı I. Alemgir (Evrenzgib)'e Mektubu," Belleten, Türk Tarih Kurumu, Cilt XIV, Nisan, Sayı 54, Ankara: Türk Tarih Kurumu Basinevi, pp. 269 \& 271.

${ }^{122}$ Francis Robinson (2010). "Introduction," in Francis Robinson (ed.), The New Cambridge History of Islam, Vol. 5, Cambridge: Cambridge University Press, p. 2. (Note: The existence of some Rumis acting in an indepent manner in some ports in the Red Sea endorses this issue.)
} 
Y1ldırım Bayezid. ${ }^{123}$ Hüsameddin Efendi born in Tabriz and moved to Rum (Anatolia) during the era of Yıldırım Bayezid. ${ }^{124}$ Arab Hakim, known as medical scientist came from Arab to Rum and settled in Uskub. ${ }^{125}$ Muhabbed Ibn Arabsyah known as religious scholar, first sent by Timurlenq to Semerkand and later on migrated to Rum during the Çelebi Sultan Mehmed Han. ${ }^{126}$ Further, there are a number of references in Ottoman archive to distinguished individuals among whom there are sheiyks of recognized tariqa orders such as Sheiyk İsmail Rumi (Tosya), ${ }^{127}$ Sheikh İsmail Rumi (Bursa), Süheyb-i Rumi (Çorum). ${ }^{128}$

There were some members among the Rumis who became renown religious scholars. For intance, Baba Daud bin Ismail al-Rumy, diciple of Syeikh Abdur Rauf as-Singkili. ${ }^{129}$ This usage reminds us to Saljuqi and Ottoman religious scholars and sufi individuals to be called as Rumi such as Maulana Jalal al-din Rumi. ${ }^{130}$ Travels' notes of Fernao Mendes Pinto also partially elucidates the existence of some Turkish religious scholars who seem to have been involving prosetlyzing activities in Siam. Pinto also refers to the home town of these individuals and mentions Constantinople, Cairo, Mecca as the cities. ${ }^{131}$ The name of Constantinople emerged again at the turning the century during the reign of Al-Mukammil in Aceh court in pertaning to the three trade vessels from Constantinople anchored in Bandar Aceh port. ${ }^{132}$ Hence, I have not come across yet any crucial reference relevant to this account in Aceh sources.

In addition to this account relevant to Siam, it is also understood that there were some Turkic elements in some islands such as Borneo, Sumatra and even Ternate, far eastern island of the Archipelago in the last decades of the 16th century. ${ }^{133}$ But I think there is either a sort of exaggeration pertaining to the number and identity of these Turks or the people who came originally from the Arabia which was then considered as the Ottoman land claimed to be Turk owing to the recognition of the former. Here it is worth reminding the account of Cemal Kafadar about the various ethnic identities, both Muslim and non-Muslim living in the house of the Ottoman could have been regarded as Turks or Ottoman. We come across almost the same understanding in Hikayat Abdullah, a well-known Malay traveller in the 19 th century. As the writer informs the readers about his origins he refers to his grandfather from Yaman but belonging to the Ottoman nation, as seen in the follow: "... moyangku laki-laki itu seorang Orang Arab, negerinya Yaman, dan bangsanya Usmani dan namanya Syekh Abdul Kadir."134

\section{Conclusion}

The references to Turkic elements in the region are related to some concepts/words which are commonly encountered are Rum, Rumi, Turcoman and Turk. The first two no doubt are a direct geographical connotation to the land of Rum and the people who were from this geography. This is not only an expression met in the adjunct geographies around the Indian Ocean, but also the various accounts and documents in Ottoman history refers to people either artisans, religious scholars, merchants etc. in a particular region in central Anatolia. Hence the rest is direct reference to the nation of Turk which seems to be independent and most probably from distinct regions.

There should be some argumentation about the material conditions of Rumis' existence in the adjunct regions of Indian Ocean. In regard to this, the seas and coastal areas of almost the whole region of Arabian sea, Western part of the Ocean, were newly emerging centers between east and west trade interactions in the end of the 15th and the beginning of the 16th century. This period witnessed not only the trade interactions among various regional elements but also a very distinct nature of various aspects

\footnotetext{
${ }^{123}$ Mehmet Süreyya (1995), Sicill-i Osmani Yahudi Tezkire-i Meşahir-i Osmaniyye (Yayına Haz.: Ali Aktan; Abdülkadir Yuvalı; Mustafa Keskin), Cilt I, İstanbul: Sebil Yayınevi, pp. 300-301 \& 354.

${ }^{124}$ Mehmet Süreyya (1995), Sicill-i Osmani Yahudi Tezkire-i Meşahir-i Osmaniyye, p. 119

${ }^{125}$ Mehmet Süreyya (1995), Sicill-i Osmani Yahudi Tezkire-i Meşahir-i Osmaniyye, p. 528.

${ }^{126}$ Mehmet Süreyya (1995), Sicill-i Osmani Yahudi Tezkire-i Meşahir-i Osmaniyye, p. 185.

127 BOA.İE.EV.71.7684.

${ }^{128}$ BOA. BEO, (1309.L.14 / 12 May 1892). See for some other usages of Rumi as epithet to scholars: Beyazlt Devlet Kütüphanesi Yazma Eserler Eser adı Katalogu, (1990). (2) M-Z, İstanbul: Türkiye Dinayet Vakfı İslam Ansikpoledisi Genel Müdürlüğü, p. 231.

${ }^{129}$ Anas M. Yunus (2009), Gerak Kebangkitan Aceh: Kumpulan Karya Sejakah M. Junus Djamil, Bandung: Bina Biladi Press, p. 313. For details see: Mehmet Özay (2017), “'Rumi’ Networks of al-Sinkili: A Biography of Baba Davud,” Studia Islamika, Vol. 24, no. 2, $247-270$.

${ }^{130}$ Howard Crane (1994), “Anatolian Saljuq Architecture and Its Links to Saljuq Iran,” p. 264.

${ }^{131}$ M. N. Pearson (2005). The World of the Indian Ocean 1500-1800: Studies in Economic, Social and Cultural History, London: Routledge, p. 59 .

${ }_{132}$ Arun Das Gupta (1962), Acheh in Indonesian Trade and Politics: 1600-1641, Cornell University, p. 67.

${ }^{133}$ M. N. Pearson (2005). The World of the Indian Ocean 1500-1800, p. 60.

${ }^{134}$ Abdullah bin Abdul Kadir Munsyi (1974). Hikayat Abdullah, Jilid I, Kuala Lumpur: Penerbitan Pustaka Antara, pp. 2 \& 31.
} 
such as needs for human resources in labor, security, army, maritime activites etc. ${ }^{135}$ In fact, this is not an unexpected development for the whole region if considered that the Arabian sea had experienced interregional exchanges from West to East and otherwise, since the Hellenistic period though these happened in different stages on the course of centuries. ${ }^{136}$

This process has a differentiated tendency in aligned with the expansion of the Turkic elements around the Indian Ocean. In this context, it is encountered with some concepts not only 'Rum' but also 'Rumi', 'Turcoman' and 'Turk' in distinct references. While there are some references in Malay world through the above-mentioned concepts, we cannot argue that there were references to Malay or Malay world in Ottoman sources at least until the late 19th century. Hence, there should be a reason that the concept of Malay has been relatively a new usage.

This idea might lead us to comprehend that Ottoman Turks did not have a direct communication and influences upon the Malay world in the field of literary interaction as argued by Vladimir Braginsky, neither the political one. But it is understood that the Turkic elements in India, beyond the impact of Saljuqi or Ottoman powers had an influence on Malay world through interactions via literary and scholarly circles. ${ }^{137}$

Though all the references to Turkic elements in the mentioned region(s), there is no any single document penned down by any 'Rumi'. In particular, it is logical to expect that some Turkic individuals, for instance, the ones who were thought to have reached to the Sultanate of Aceh Darussalam by the order of the Ottoman court both in the late decades of the 16th century or the ones, who were mentioned in Hikayat Aceh, and Bustanu's Salatin early decades of the 17th century must have written any travellers' notes or left any agreements with local rulers. ${ }^{138}$ Against all odds, the account of Seydi Ali Reis should be regarded as an exception and even it is not much relevant to the realities of the port cities in the region. The other paper which was written during the Diu expedition belongs to a Hungarian slave soldier, not from a Rumi. ${ }^{139}$

In this regard, a one-way reference or the mutual references between Turkish-Malay world can be assumed to be a result of the Turks being considered as an 'eastern' nation before the European maritime nations' expansion towards the Indian Ocean and initiated the colonialism. On the other hand, there would be a less opportunity for any sorts of interactions between both nations, say, Turks and Malays since the climate, transportation, production systems and migration processes of both nations differentiated from each other. As it is known that Turks is acknowledged as a land-based state, while the Malay mostly maritime nations.

On the other hand, I can assert that the rulers of Malay principalities and the anonymous texts referring to Rum to some or larger extent had intentionally an approach on the basis of religious victory of the Turks over conquering Constantinople, the capital city of Eastern Rome. And by this referring they nominally or symbolically would mean to acquire the same honor as well. And though some Western researchers emphasize more on the reformist approach of Mehmed the Conqueror rather than his expansion of border of the Ottomans till conquering Constantiople as a strong religious bound on the basis of the hadith prophetysing the event, ${ }^{140}$ not worldly attempt but the sacred connotation of this conquer more exist and valid in the understanding of the Malay societies.

Though all these mentioned references about the existence of Turkic groups in the region, there need to have signification testification what sorts of dynamic interactions emerged throughout their being in alien lands. In addition, it remains to discover that what these individuals or groups learent from their experiences and what they transmitt to their home land need to be subjects of extensive researches to be able to acquire private letters, contracts, account books, travel notes covering all relevant countries' libraries and archives "...the merchants' hometowns and the nature or less frequently the amount of their merchandise, as well as their routes and means of travel, can be gathered from these sources."

\footnotetext{
${ }^{135}$ R. J. Barendse (2002), The Arabian Seas: The Indian Ocean World of the Seventeeth Century, Armonk: An East Gate Book, p. 8.

${ }^{136}$ R. J. Barendse (2002), The Arabian Seas: The Indian Ocean World of the Seventeeth Century, p. 6.

137 Vladimir Braginsky (2015), "Introduction," pp. 6-7.

${ }^{138}$ T. Iskandar (1966), Bustanu's-Salatin, p. 40.

${ }_{139}$ Palmira Brummett (1994), Ottoman Seapower and Levantine Diplomacy in the Age of Discovery, Albany: State University of New York Press, p. 120.

${ }^{140}$ Franklin D. Margiotta (1994), Brassey's Encyclopedia of Military History and Biography, Washington: Brassey’s, p. 748.
} 


\section{References}

BOA (Başkanlık Osmanlı Arşivleri- Ottoman Archives)

İ.HR.66.3208.6.1. (29.B.1266 / 10 Haziran 1850).

İ.HR.173.9431.3.1. (1276.C.04 - 29 December 1859)

İE.EV.71.7684.

TS.MAe.1304.67.(1248.Z.1 / 21 April 1833).

TT.D.287 / 961.Z.29 (25 November 1554).

Y.EE.37.104/1327.R.06.(1) (27 April 1909).

Vernacular Press

Oendang Oendang van Sumatra's Westkust, Ms. Orient Oct. 1111 (Malaiisch) Akzessionnummer: 1906.284. Or 637 (146) Malay manuscript/Laufende Nr. 2. (1-9).

"Moelanja Igama Islam diketahoei di Minangkabau", Fadjar Islam, No. 15, Djoem'at 31 Januari 1930 / 1 Ramadhan 1348, Tahoen II.

Secondary Sources

A Handbook for Travelers in Indian and Pakistan, Burma and Ceylon (n.d.), sixteenth edition, London: John Murray.

Abdullah, Imran Teuku (1991), Hikayat Meukuta Alam: suntingan teks dan terjemahan beserta teuaah strüktur dan resepsi, PhD Dissertation, Seri İldep, Jakarta: Intermasa.

Abdul Jalil, Tuanku (1980), "Sebab Aceh Dinamakan Serambi Mekkah," Seminar Sejarah Masuk Dan Berkembangnya Islam Di Aceh Dan Nusantara, Aceh Timur, 25-30 September 1980.

Alfian, İbrahim (2006), “Islam Dan Kerajaan Aceh Darussalam," in Taufik Abdullah (ed.), Sejarah Dan Dialog Peradaban, Jakarta: LIPI Press.

Alfian, Ibrahim (2005), "Kerajaan Aceh Darussalam: Sebuah Wacana Singkat," Prosiding Seminar Antrabangsa Kesultanan Melayu Nusantara: Sejarah dan Warisan, 8-11 Mei, Kuantan Pahang Darul Makmur, Lembaga Muzium Negeri Pahang dan Institute Alam \& Tamadun Melayu UKM, Bangi, 319415 .

Anderson, John (1839), Political and Commercial Considerations Relative to the Malayan Peninsula and the British Settlements in the Straits of Malacca, Vol. II, London: John Murray.

Arnold, T. W. (1968), The Preaching of Islam: A History of the Propagation of the Muslim Faith, Third Reprint, SH. Muhammad Ashraf.

Andaya, Barbara Watson (1977), "From Rum to Tokyo: The Search for Anticolonial Allies by the Rulers of Riau, 1899-1914," Indonesia, Vol. 24, 123-156.

Ayyubi, Akmal (1960), "Hint Kültürü Üzerinde Müslüman Türk Tesirleri,” in İslam Tetkikleri Enstitüsü Dergisi, Vol. III, 1-2 Kısım, İstanbul: İ̈EF Yayınları, 205-210.

Azra, Azyumardi (2004), The Origins of Islamic Reformism In Southeast Asia: Networks of Middle Eastern and Malay-Indonesian 'Ulama' In The Seventeenth and Eighteenth Centuries, Allen\&Unwin ve University of Hawaii Press Honolulu.

Badger, George Percy (1863), The Travels of Ludovico di Varthema, The Hakluyt Society, 32, London: Printed for the Hakluyt Society.

Bagley, F. R. C. (1969), “The Ottoman Empire to 1774," in The Muslim World: A Historical Survey, Part III: The Last Great Muslim Empires, Leiden: E. J. Brill, 50-97. 
Journal of Al-Tamaddun, Vol. 15 (1), 2020, 31-58

Barendse, R. J. (2002), The Arabian Seas: The Indian Ocean World of the Seventeeth Century, Armonk: An East Gate Book.

Bates, Ülkü Ü. (1994), "Evliya Çelebi's Comments on the Saljuqs of Rum," in Robert Hillenbrand (ed.), The Art of the Saljuqs in Iran and Anatolia: Proceedings of a Smyposium held in Edinburgh in 1982, California: Mazda Publishers, 257-262.

Bayur, Hikmet (1950), “Osmanlı Padişahı II. Süleyman'1n Gurkanlı Padişahı I. Alemgir (Evrenzgib)'e Mektubu," Belleten, Türk Tarih Kurumu, Cilt XIV, Nisan, Sayı 54, Ankara: Türk Tarih Kurumu Basinevi, 269-285.

Beyazıt Devlet Kütüphanesi Yazma Eserler Eser adı Katalogu, (1990). (2) M-Z, İstanbul: Türkiye Dinayet Vakfi İslam Ansikpoledisi Genel Müdürlüğü.

Boxer, C. R. (1996), "A Note on Portuguese Reactions to the Revival of the Red Sea Spice Trade and the Rise of atjeh: 1540-1600," in M. N. Pearson (ed.), Spices in the Indian Ocean World, Variorum.

Braginsky, Vladimir (2015), "Introduction," The Turkic-Turkish Theme in Traditional Malay Literature: Imagining the Other to Empower the Self, Ledien: Brill, 1-8.

Brummett, Palmira (1994), Ottoman Seapower and Levantine Diplomacy in the Age of Discovery, Albany: State University of New York Press.

Carey, Peter (ed.) (1992), The British in Java 1811-1816: A Javanese Account, (British Library Additional Manuscript 12330) (Babad Bedhah ing Ngayogyakarta), The British Academy, Oxford University Press.

Clarence-Smith, William (2010), "South-east Asia and China to 1910," in Francis Robinson (ed.), The New Cambridge History of Islam, The Islamic World in the Age of Western Dominance, Vol. 5, Cambridge: Cambridge University Press, 240-268.

Coatalen, Paul (1981), "The Coming of Islam to Southeast Asia: A Critical Review of Some Extant Theories," The Islamic Quarterly, Vol. XXV, no. 3 \& 4, 100-121.

Commissariat, M. S. (1921-1923), "A Brief History of the Gujarat Saltanat,” The Journal of the Bombay Branch of the Royal Asiatic Society, Vol. XXVI, 99-157.

Conrad, Lawrence I. (2004), "Theophanes and the Arabic Historical Tradition: Some Indicationas of Intercultural Transmission," in Michael Bonner (ed.), Arab-Bytantine Relations in Early Islamic Times, Vol. 8, Surrey: Ashgate-Variorum.

Couto, Dejanirah (ed.) (2010), "Giriş," Harp ve Sulh: Avrupa ve Osmanlılar, Dejanirah Couto, Şirin Tekeli (trans.), İstanbul: Kitap Yayınevi, 13-46.

Crane, Howard (1994), “Anatolian Saljuq Architecture and Its Links to Saljuq Iran," in Robert Hillenbrand (ed.), The Art of the Saljuqs in Iran and Anatolia: Proceedings of a Smyposium held in Edinburgh in 1982, California: Mazda Publishers, 263-268.

Çelebi, Kütahyalı Firaki Abdurrahman (2013), Se'adetname-Yavuz sultan Selim Han ve Kanuni Sultan Süleyman Han'ın Gazaları (Haz.: Şaban Er), İstanbul: Kutupyıldızı Yayınları.

D. Goodrich, Thomas (1990), The Ottoman Turks and the New World: A Study of Tarih-i Hind-i Garbi and Sixteenth Century Ottoman Americana, Wiesbaden: Otto Harrassowitz.

'D'Albuquerque in Malacca', The Portuguese Period, JMBRAS, Vol. XIII, Part I, March, 1935, Singapore. 
Dames, M. Longworth (1921) "The Portuguese and Turks in the Indian Ocean in the Sixteenth Century," The Journal of the Royal Asiatic Society, 1-28.

Danvers, Frederick Charles (1966), The Portuguese in India: Being a History of the Rise and Decline of Their Eastern Empire, II. Bask1, Vol. I, London: Frank Cass.

Daneshgar, Majid (2016), "Dhu 1-Qarnayn in modern Malay commentaries and other literature on Qur'anic themes," in Majid Daneshgar, Peter G. Riddell \& Andrew Rippin (eds.), The Qur'an in the Malay-Indonesian World: Context and Interpretation, London: Roudledge, 212-228.

Das Gupta, Arum Komar (1993), "Iskandar Muda and The Europeans," in Ali Hasjmy (ed.), Sejarah Masuk Dan Berkembangnay Islam di Indonesia, Edisi Ketiga, Ptalmaarif.

Das Gupta, Arun (1962), Acheh in Indonesian Trade and Politics: 1600-1641, Cornell University.

De Klerck, E. S. (1938), History of the Netherlands East Indies, Vol. I, Rotterdam: W. L.\&J. Brusse N. $\mathrm{V}$.

Divekar, V. D. (1979), "Maritime Trading Settlements in the Arabian Sea Region Up To 1500 A.D.," in 'The Indian Ocean in Focus' International Conference on Indian Ocean Studies, Section III The History of Commercial Exchange \& Maritime Transport, Perth Western Australia.

Djajadiningrat, Raden Hoesein (1982/83), Kesultanan Aceh, Teuku Hamid (trans.), Departemen Pendidikan dan Kebudayaan Proyek Pengembangan Permuseuman Daerah Istimewa Aceh.

Fatimi, Sayyid Qudratullah (n.d.), Islam in Malaya: The Historical Perspective, Part I (Visiting professor in Urdu \& Pakistani Studies University of Malaya, Singapore), Leiden Library Special Collections.

Goitein, S. D. (2014), "Mediterranean Trade in the Eleventhy Century: Some Facts and Problems," in Studies in the Economic History of the Middle East: From the rise of Islam to the present day, London: Routledge, 51-62.

Fansuri, Hamzah, Kitab-al-Muntahi, In Laufende Nr. 2, Ms. Orient Oct. 1111 (Malaiisch) Akzessionnummer: 1906.284, Cod.Or.5716.(2), Or 637 (146) Malay manuscript, Akzessionnummer: 1906.287, Leiden University Library.

Farlane, Charles Mac (1854), History of British India, London: Routledge.

Furber, Holder (1976), Rival Empires of Trade in the Orient: 1600-1800, Minneapolis: University of Minnesota Press.

Gottfried, Hagen (2015), Bir Osmanlı Coğrafyacısı İşbasında: Katip Çelebi’nin Cihannüma'sı ve Düşünce Dünyası (Çev.: Hilal Görgün), İstanbul: Küre Yayınları.

H. Fleischer, Cornell (1986), Bureaucrat and Intellectual in the Ottoman Empire, Princeton: Princeton University Press.

Hamka (1977), Sejarah Umat Islam, (second printing), Singapura: Pustaka Nasional Pte. Ltd.

Harris, John (MDCCV) (1705). "The Voyages and Travels of Mr. John Albert de Mandelslo Into the East-Indies In the Years 1638, 1639, 1640 Containing and Particular Description of the Empire of the Great Moghul," in A Complete Collection of Voyages and Travels, (Navigantium atque Itinerantium Bibliotheca), Vol. II, London: Printed for Thomas Bennet.

Higgins, Lawrence D. (1994a), "Turkic Empire," in Franklin D. Margiotta (ed.), Brassey's Encyclopedia of Military History and Biography, Washington: Brassey’s, 1004-1009. 
Journal of Al-Tamaddun, Vol. 15 (1), 2020, 31-58

Higgins, Lawrence D. (1994b), "Ottoman Empire," in Franklin D. Margiotta (ed.), Brassey's Encyclopedia of Military History and Biography, Washington: Brassey’s, 746-754.

Hinz, Walther (1992), Uzun Hasan ve Şeyh Cüneyd: XV. Yüzyllda İan'ın Milli Bir Devlet Haline Yükselişi, (Çev.: Tevfik Bıyıklığlu', Atatürk Kültür Dil ve Tarih Yüksek Kurumu, Türk Tarih Kurumu Yayınları, IV. Dizi, Sa. 5, Ankara: Türk Tahik Kurumu Basımevi.

İbn Fazlan (1975), İbn Fazlan Seyahatnamesi: Onuncu Asırda Türkistan'da bir İslam Seyyahı, Ramazan Şeşen (trans.), İstanbul: Bedir Yayınevi.

İnalc1k, Halil \& Quataert, Donald (eds.) (2005), An Economic and Social History of The Ottoman Empire, Vol. I: 1300-1600, fifth printing, Cambridge: Cambridge University Press.

İnalcık, Halil (1948), "Osmanlı-Rus Rekabetinin Menşei ve Don-Volga Kanalı Teşebbüsü (1569)," Belleten, Türk Tarih Kurumu Cilt XII, Sayı 46, (Nisan), 349-402.

İnalc1k, Halil (1964), "The Place of the Ottoman-Turkish Empire in History," Cultura Turcica, Institute for the Study of Turkish Culture, Volumen I, Numerus I, Ankara, 57-64.

İnalc1k, Halil (1973), The Ottoman Empire: The Classical Age 1300-1600, Norman Itzkowitz \& Colin Imber (trans.), London: Weidenfeld and Nicolson.

İnalc1k, Halil (2014), "The Ottoman Economic Mind and Aspects of the Ottoman Economy," in Studies in the Economic History of the Middle East: From the rise of Islam to the present day, London: Routledge, 207-218.

İnalcık, Halil (2017), Devlet-i 'Aliyye: Osmanlı İmparatorluğu Üzerine Araştırmalar-II, 5. Bask1, İstanbul: Türkiye İş Bankası Kültür Yayınları.

İnegöllüoğlu, Metin (1998), Asya-Pasifik'te Türk İzleri, Manisa: Celal Bayar Üniversitesi Yayınları.

Iskandar, T. (1958), De Hikajat Atjeh, S. Gravenhage-Martinus Nijhoff.

Iskandar, T. (1966), Bustanu's-Salatin, (Nuru'd-din ar-Raniri), Bab II, Fasal 13, Kuala Lumpur: Dewan Bahasa dan Pustaka.

Iskandar, T. (1978), Hikayat Aceh: Kisah Kepahlawanan Sultan Iskandar Muda, (Çev.: Aboe Bakar), Proyek Rehabilitasi Dan Perluasan Mesuem Daerah Istimewa Aceh, Seri Publikasi Nomor 1.

Isom-Verhaaren, Christine (2014), "Was there Room in Rum for Corsairs?: Who Was an Ottoman in the naval Forces of the Ottoman Empire in the 15th and 16th Centuries?" The Journal of Ottoman Studies, Vol. 44, 235-264.

Johns, A. H. (1993), "Political Authority in Islam: Some Reflections Relevant to Indonesia," in Anthony Reid (ed.), The Making of An Islamic Political Discourse in Southeast Asia, Aristoc Press Pty, Centre of Southeast Asian Studies, Monash University, Clayton-Victoria, Australia.

Kafadar, Cemal (1996), "A Death in Venice (1575): Anatolian Muslim Merchants Trading in the Serenissima," in Sanjay Subrahmanyam ed.), Merchant Networks in the Early Modern World, Aldershot: Varioum, 97-124.

Kafadar, Cemal (2007), “A Rome of One's Own: Reflections on Cultural Geography and Identity in the Lands of Rum," Muqarnas, Vol. 24, 7-25.

Kamil, Ekrem, Gazzi-Mekki Seyahatnamesi, (Hicri Onuncu- Miladi on altınc1 asırda yurdumuzu dolaşan Arab Seyahlardan), Tarih Semineri Dergisi 1-2, İstanbul Üniversitesi Edebiyat Fakültesi Yayınları, III, İstanbul: Milli Mecmua Basımevi. 
Koca, Salim (1995), "Türkiye Selçuklu Sultanı I. İzzeddin Keykavus'un Aldığ1 ve Kullandığı Hakimiyet Sembolleri," Belleten, Atatürk Kültür Dil ve Tarih Yüksek Kurumu, Türk Tarih Kurumu, Cilt LIX, S. 224, (Nisan), Ankara: Türk Tarih Kurumu Basımevi, 55-74.

Köprülü, M. Fuad (1984), İslam Medeniyeti Tarihi, Altıncı Basım, Diyanet İşleri Başkanlığı Yayınları, No. 86, Ankara: Arısan Matbaacilık.

Köseoğlu, Nevzat (1991), Türk Dünyası Tarihi ve Türk Medeniyeti Üzerine Düşünceler, İstanbul: Ötüken Yayınları.

Kunt, Metin (1984), "The Later Muslim Empires: Ottomans, Safavids, Mughals," in Marjorie Kelly (ed.), Islam: The Religious and Political Life of a World Community, New York: Praeger.

Kunt, Metin, Yurdaydın, Hüseyin G. \& Ödekan, Ayla (1988), Türkiye Tarihi (2), Osmanlı Devleti: 1300-1600, İstanbul: Cem Yayınevi.

Kurtoğlu, Fevzi (1940), "Hadım Süleyman Paşa'nın Mektupları ve Belgradın Muhasara Planı," Belleten, Cilt IV, Türk Tarih Kurum, Ankara, Türk Tarih Kurumu Basımevi.

Leupe, P. A. (1988), "Letter Transport Overland to the Indies by the East India Company," in M. A. P. Meilink-Roelofsz, M. E. Van Opstall \& G. J. Schutte (eds.), Dutch Authors on Asian History: A Selection of Dutch Historiography on the Verenigde Oostindische Compagnie, Dordrecht-Holland: Foris Publications, 77-90.

Levi, Scott (2007), "Turks and Tajiks in Central Asian History," in Jeff Sahadeo \& Russell Zanca (eds.), Everday Life in Central Asia Past and Present, Bloomington: Indiana University Press, 15-32.

Lewis, Dianne (1995), Jan Compagnie in the Straits of Malacca 1641-1795, Athens: Ohio University Center for International Studies Center, Southeast Asia Series, No. 96.

Lukman, Rachman (1983), Sejarah Perlawanan Terhadap Kolonialisme dan Imperialisme di Jambi, Proyek Inventarisasi dan Dokumentasi Sejarah Nasional, Jakarta: Departemen Pendidikan dan Kebudayaan.

Lukman, Hajar, Zaituni \& Munawir, M. Nazir (1992-1993), Sejarah Perlawanan Terhadap Kolonialisme dan Imperialisme di Jambi, Departemen Pendidikan dan Kebudayaan Proyek Inventarisasi dan Dokumentasi Sejarah Nasional.

M. Yunus, Anas (2009), Gerak Kebangkitan Aceh: Kumpulan Karya Sejakah M. Junus Djamil, Bandung: Bina Biladi Press.

Marong Mahawangsa: The Keddah Annals (2012), Kuala Lumpur: Silverfish Books.

Margiotta, Franklin D. (1994), Brassey's Encyclopedia of Military History and Biography, Washington: Brassey's.

Marrison, G. E. (1955), "Persian Influences in Malay Life: 1280-1650," Journal of the Malaysian Branch of the Royal Asiatic Society, Vol. 28, Part I, no. 169.

Melalatoa, M. J. (1982), Kebudayaan Gayo, Catatan Kedua, Seri Etnografi Indonesia, No. 1, Jakarta: PN Balai Pustaka.

Moorhbad, F. J. (1957), A History of Malaya and Her Neighbours, Volume One, London: Longmans.

Mughul, Muhammad Yakub (1987), Kanuni Devri, Ankara: Kültür ve Turizm Bakanlığı Yayınları.

Munsyi, Abdullah bin Abdul Kadir (1974), Hikayat Abdullah, Jilid I, Kuala Lumpur: Penerbitan Pustaka Antara. 
Journal of Al-Tamaddun, Vol. 15 (1), 2020, 31-58

$\mathrm{Ng}$, Su Fang (2006), "Global Renaissance: Alexander the Great and Early Modern Classicism from the British Isles to the Malay Archipelago," Comparative Literature, Vol. 58, no.4, 293-312.

Nugraha, Nindya (2002), Hikayat Iskandar Zulkarnain\&Syair Raja Siak, Dari Naskah W113\&W273, Jakarta: Perpustakaan Nasional RI.

Oruç Bey Tarihi, (Haz.: Necdet Öztürk), İstanbul: Çamlıca Basım Yayın.

Othman, Mohemad Redzuan (1997), "The Malay Peninsula," in Ulrike Freitag \& William G. ClarenceSmith (eds.), Hadhrami Traders, Scholars and Statesmen In The Indian Ocean, 1750s-1960s, Ledien: Brill, 83-97.

Özay, Mehmet \& Saltık, Ekrem (2015), "The Myth and Reality of Rukiye Hanım in the Context of Turkish Malay Relations (1864-1904),” The Journal of Human\&Society, Vol. 4, no. 9, 55-74.

Özay, Mehmet (2017). “'Rumi’ Networks of al-Sinkili: A Biography of Baba Davud,” Studia Islamika, Vol. 24, no. 2, 247-270.

Özay, Mehmet (2018), Açe Darüsselam Sultanlı̆̆l: İslam öncesi dönemden 20. yüzyll başlarına kadar Açe tarihi, İstanbul: Fatih Sultan Mehmet Vakıf Üniversitesi Yayınları.

Özbaran, Salih (1972), "The Ottoman Turks and The Portuguese in the Persian Gulf, 1534-1581," Journal of Asian History, Vol. 6, 45-87.

Özbaran, Salih (2007), "Osmanlılar ve Deniz: 16. Yüzyıl Hint Okyanusu Bağlamında Yeniden Bakış," in Özlem Kumrular (ed.), Türkler ve Deniz, İstanbul: Kitap Yayınevi.

Özkılınç, Ahmet, Coşkun, Ali, Ergün, Gülşen, Karazeybek, Mustafa, Sivridağ, Abdullah, Yüzbaşığlu, Murat (1996), (Haz.). Muhasebe-i Vilayet-i Karaman ve Rum Defteri. (937/1530), I, Konya, Bey-şehri, Ak-şehir, Larende, Aksaray, Niğde, Kaseriyye ve İç-il Livaları, Ankara: T.C. Başbakanlık Devlet Arşivleri Genel Müdürlüğü Osmanlı Arşivi Daire Başkanlığı Yayın Nu. 32, Defter-i Hakani Dizisi: III, 387 Numaral1.

Öztuna, Y1lmaz (1983), Büyük Türkiye Tarihi -Başlangıcından Zamanımıza Kadar-, Dördüncü Cilt, İstanbul: Ötüken Yayınevi.

Pearson, M. N. (2005), The World of the Indian Ocean 1500-1800: Studies in Economic, Social and Cultural History, London: Routledge.

Pearson, M. N. (1979), "Across the Black Water Indian Seafarers in the Sixteenth Century," in 'The Indian Ocean in Focus' International Conference on Indian Ocean Studies, Section III The History of Commercial Exchange\&Maritime Transport, Perth Western Australia.

Piet, Na Tian (1896), Shaer Almarhoem Beginda Sultan Abubakar Di Negeri Johor, Bagian Yang Pertama.

Pintado, M. J. (ed.) (1993), Portuguese Documents on Malacca, Vol. 1: 1509-1511, Kuala Lumpur: National Archieves of Malaysia.

Pinto, Fernao Mendes (1989), The Travels of Mendes Pinto, Rebecca D. Catz (ed.), Chicago: The University of Chicago Press.

Pinto, Fernao Mendes (1897), The Voyages and Adventures of Ferdinand Mendez Pinto, Henry Cogan (trans.), London: T. Fisher Unwin.

Pinto, Karen C. (2016), Medieval Islamic Maps: An Exploration, Chicago: The University of Chicago Press. 
Raffles, Sophia (1830), Memoir of the Life and Public Services of Sir Thomas Stamford Raffles, London: John Murray.

Reid, Anthony (1969), "Indonesian Diplomacy A Documentary Study of Atjehnese Foreign Policy in the Reign of Sultan Mahmud: 1870-4," JMBRAS, Volume XLII, Part 2.

Reid, Anthony (ed.) (1995), Witnesses to Sumatra: A Travellers' Anthology, Kuala Lumpur: Oxford University Press.

Robinson, Francis (2010), "Introduction," in Francis Robinson (ed.), The New Cambridge History of Islam, Vol. 5, Cambridge: Cambridge University Press, 1-28.

Ross, E. Denison (1929), "Nomadic Movements in Asia," Journal of the Royal Society of Arts, Vol. 77, no. $4010,1075-1086$.

Rowen, John R. (1989), "Narrative Form and Political Incorporation: Changing Uses of History in Aceh, Indonesia," Society for Comparative Study of Society and History, Vol. 31, no. 4, 671-693.

Saffet Bey (1329/1909), "Bir Osmanlı Filosunun Sumatra Seferi," Tarih-i Osmani Encümeni Mecmuas1, 1, 604-614.

Salleh, Muhammad Haji (1997), "Pengenalan," in Sulalat al-Salatin, (Dikaji dan diperkenalkan), Kuala Lumpur: Yayasan Karyawan dan Dewan Bahasa dan Pustaka, xi-xlviii.

Shacke, Christopher (2000), "Beyond Turk and Hindu: Crossing the Boundaries in Indo-Muslim Romance," in Beyond Turk and Hindu: Rethinking Religious Identities in Islamicate South Asia, Gainesville: University Press of Florida, 55-73.

Seljuq, Affan (1980), "Relations Between The Ottoman Empire and the Muslim Kingdoms in the Malay-Indonesian Archiapeloge," Der Islam, Vol. 57, 301-10.

Seydi Ali Reis (n.d.), Mir'at-ül Memalik: Ülkelerin Aynası, Baskıya Hazırlayan: Necdet Akyıldız, Tercüman 1001 Temel Eser, İstanbul.

Siddiqi, Iqtidar Husain (1994), "The Turks and Their Migration To Central Asia and India," Proceedings International History Congress (IHC), 55th Session, 176-185.

Smith, Wilfred Cantwell (1957), Islam in Modern History, Princeton: Princeton University Press

Strange, Guy Le (2015), Doğu Hilafetinin Memleketleri (Mezopotamya, Iran ve Orta Asya) İslam Fetihlerinden Timur Zamanına Kadar, (Haz.: Adnan Eskikurt; Cengiz Tomar), İstanbul: Yeditepe Yayınları.

Subramanian, Lakshmi (1999), "Introduction," in The French East India Company and the Trade of the Indian Ocean, Calcutta: Munshiram Manoharlal.

Subrahmanyam, Sanjay (1997), "The Coromandel Malacca Trade in the Sixteenth Century: A Study of its Evolving," in Om Prakash (ed.), European Commercial Expansion in Early Modern Asia, Volume 10, Aldershot: Varioum.

Süreyya, Mehmet (1995), Sicill-i Osmani Yahudi Tezkire-i Meşahir-i Osmaniyye, (Yayına Haz.: Ali Aktan; Abdülkadir Yuval1; Mustafa Keskin), Cilt I, İstanbul: Sebil Yayınevi.

Tekindağ, Şahabettin (1968), "Süveyş’de Türkler ve Selman Reis'in Arızas1," Belgelerle Türk Tarihi Dergisi, Cilt 2, Say1 9, Haziran, 77-80.

Truhart, Peter (1996), Historical Dictionary of States: States and State-like Communities from Their Origins to the Present, München: K. G. Saur. 
Journal of Al-Tamaddun, Vol. 15 (1), 2020, 31-58

Türkdoğan, Orhan (2002), Osmanlıdan Günümüze Türk Toplum Yapısı, İstanbul: Çamlıca Yayınları.

Uzunçarşı1ı, İsmail Hakkı (1951), Osmanlı Tarihi, III. Cilt, I. Kısım, Türk Tarih Kurumu Yayınlarından XIII. Seri, No. 16, Ankara: Türk Tarih Kurumu Basımevi.

Van Leur, J. C. (1967), Indonesian Trade and Society: Essays in Asian Social and Economic History, W. Van Hoeve Publishers Ltd-The Hague.

Yusuf, S. M. (1970), Studies in Islamic History and Culture, Lahore: Institute of Islamic Culture. 